\title{
Onkoreumatológia: a daganatos és mozgásszervi kórképek összefüggései
}

\author{
Szekanecz Zoltán dr. ${ }^{1}$ - Gomez Izabella dr. ${ }^{1,7}$ - Soós Boglárka dr. ${ }^{1}$ \\ Bodoki Levente dr. ${ }^{1}$ - Szamosi Szilvia dr. ${ }^{1}$ - András Csilla dr. ${ }^{4}$ \\ Juhász Balázs dr. ${ }^{4}$. Váróczy László dr. ${ }^{2}$. Antal-Szalmás Péter $\mathrm{dr} .^{5}$ \\ Szodoray Péter dr. ${ }^{3,10}$. Bittner Nóra dr. ${ }^{6}$. Árkosy Péter $\mathrm{dr}^{4}{ }^{4}$ \\ Illés Árpád dr. ${ }^{2}$ - Szúcs Gabriella dr. ${ }^{1}$ - Dankó Katalin dr. ${ }^{3}$ \\ Bender Tamás dr. ${ }^{8}$. Tamási László dr. ${ }^{9}$ - Szekanecz Éva dr. ${ }^{4}$ \\ ${ }^{1}$ Debreceni Egyetem, Általános Orvostudományi Kar, Klinikai Központ, Belgyógyászati Intézet, \\ Reumatológiai Tanszék, Debrecen \\ ${ }^{2}$ Debreceni Egyetem, Általános Orvostudományi Kar, Klinikai Központ, Belgyógyászati Intézet, \\ Hematológiai Tanszék, Debrecen \\ ${ }^{3}$ Debreceni Egyetem, Általános Orvostudományi Kar, Klinikai Központ, Belgyógyászati Intézet, \\ Klinikai Immunológiai Tanszék, Debrecen \\ ${ }^{4}$ Debreceni Egyetem, Általános Orvostudományi Kar, Klinikai Központ, Onkológiai Klinika, Debrecen \\ ${ }^{5}$ Debreceni Egyetem, Általános Orvostudományi Kar, Klinikai Központ, \\ Laboratóriumi Medicina Intézet, Debrecen \\ ${ }^{6}$ Debreceni Egyetem, Általános Orvostudományi Kar, Klinikai Központ, Tüdőgyógyászati Klinika, Debrecen \\ ${ }^{7}$ Országos Reumatológiai és Fizioterápiás Intézet, Budapest \\ ${ }^{8}$ Budai Irgalmasrendi Kórház, Budapest \\ ${ }^{9}$ Borsod-Abaúj-Zemplén Megyei Központi Kórház és Egyetemi Oktatókórház, Szent Ferenc Tagkórház, \\ Reumatológiai Osztály, Miskolc \\ ${ }^{10}$ Institute of Immunology, Rikshospitalet, Oslo University Hospital, Oslo, Norvégia
}

\begin{abstract}
Az onkoreumatológia a daganatképződés és a reumatológiai kórképek kapcsolatát jelenti. Számos összefüggés van a két orvosi szakterület között. Ezek egy része a reumatológiai kórképben szenvedő betegben jelentkező daganatokat, a másik fele pedig a daganatos betegen fellépő mozgásszervi jelenségeket foglalja magában. Az előbbi csoport keretében a reumatológiai betegségekben jelentkező szekunder tumorokat, a tumorasszociált antigének reumatológiai szerepét, a mozgásszervi betegségek kezelésére használt hagyományos és célzott terápiák esetleges onkogenitását és a korábban vagy jelenleg daganatos, mozgásszervi betegek fizioterápiáját tárgyaljuk. A másik nagy csoport magában foglalja a paraneoplasiás szindrómákat, az onkológiai kezelések (kemoterápia és immunterápia) lehetséges autoimmun-reumatológiai mellékhatásait, a hormondeprivatiós kezelés csonthatásait és a mozgásszervrendszer primer és szekunder daganatait.
\end{abstract}

Orv Hetil. 2020; 161(28): 1151-1165.

Kulcsszavak: onkoreumatológia, mozgásszervi betegségek, daganatok, szekunder daganatképződés, carcinogenitas, célzott terápia, immuncheckpointgátlók, sarcomák

\section{Oncorheumatology: relationship between malignancies and musculoskeletal diseases}

Oncorheumatology is the meeting point of tumour formation and rheumatic diseases. Multiple interactions exist between these two medical specialties. One major field is the topic of malignancies associated with rheumatic diseases, while the other topic covers the development of musculoskeletal disease in cancer patients. In the first group, secondary malignancies associated with rheumatic diseases, role of tumour-associated antigens in rheumatology, the possible carcinogenicity of conventional and targeted antirheumatic drugs and physical therapy of rheumatic patients with recent or current cancer will be discussed. The second large topic includes paraneoplastic syndromes, autoimmune-rheumatic side effects of oncotherapies (chemotherapy and immunotherapy), effects of hormone-deprivation therapies on bone and primary and secondary malignancies of the musculoskeletal system. 
Keywords: oncorheumatology, musculoskeletal diseases, tumours, secondary tumour development, carcinogenicity, targeted therapy, immune-checkpoint inhibition, sarcomas

Szekanecz Z, Gomez I, Soós B, Bodoki L, Szamosi Sz, András Cs, Juhász B, Váróczy L, Antal-Szalmás P, Szodoray P, Bittner N, Árkosy P, Illés Á, Szű́cs G, Dankó K, Bender T, Tamási L, Szekanecz É. [Oncorheumatology: relationship between malignancies and musculoskeletal diseases]. Orv Hetil. 2020; 161(28): 1151-1165.

(Beérkezett: 2020. március 22.; elfogadva: 2020. április 6.)

\section{Rövidítések}

5-FU = 5-fluorouracil; ALPS $=$ autoimmun lymphoproliferativ szindróma; $\mathrm{APC}=($ antigen-presenting cell $)$ antigénprezentáló sejt; APRIL = (A PRoliferation Inducing Ligand $)$ proliferációt indukáló ligand; APS $=($ antiphospholipid syndrome $)$ antifoszfolipid-szindróma; $\mathrm{AT}=$ ataxia teleangiectasia; $\mathrm{AZA}=$ azatioprin; $\mathrm{BAFF}=(\mathrm{B}$ cell activating factor $) \mathrm{B}$-sejt-aktiváló faktor; bDMARD = biológiai terápia; betegséglefolyást módosító reumaellenes szer; BMP $=$ (bone morphogenetic protein $)$ csont morfogenetikus fehérje; BRAF $=$ (rapidly accelerated fibrosarcoma isoform B) a rapidan gyorsuló fibrosarcoma B-izoformája; CAM = (cancer-associated myositis $)$ daganatokhoz társuló myositis; CAPS $=($ catastrophic APS $)$ katasztrofális APS; CEA $=$ carcinoembryonalis antigén; $\mathrm{CI}=$ (confidence interval) konfidenciaintervallum; CRP $=$ C-reaktív protein; CTLA $=$ citotoxikus-T-lymphocyta-antigén; CYC = ciklofoszfamid; CsA = ciklosporin A; csDMARD = (conventional synthetic DMARD $)$ konvencionális szintetikus (bázis)terápia (metotrexát, ciklofoszfamid, azatioprin $) ; \mathrm{DC}=($ dendritic cell $)$ dendritikus sejt; DEXA $=$ (dual-energy X-ray absorptiometry) kettős energiájú röntgensugár-elnyelődés mérése; $\mathrm{DM}=$ dermatomyositis; DMARD $=$ (disease-modifying antirheumatic drug) betegséglefolyást módosító reumaellenes szer; DNS = dezoxiribonukleinsav; EBV = Epstein-Barr-vírus; FGF23 = (fibroblast growth factor-23) fibroblastnövekedési faktor-23; $\mathrm{GnRH}=$ (gonadotropin-releasing hormone) gonadotropinfelszabadító hormon; $\mathrm{HCL}=$ (hairy cell leukemia) hajas sejtes leukaemia; HIFl $\alpha=$ hypoxiaindukált faktor-1-alfa; HK = Hodgkin-kór; HOA = hypertrophiás osteoarthropathia; ICI = immuncheckpointinhibitor; IGF = (insulin-like growth factor) inzulinszerű növekedési faktor; IIM = idiopathic inflammatory myositis; IL = interleukin; JAK = (Janus kinase $)$ Janus-kináz; JIA = juvenilis idiopathiás arthritis; MDS = myelodysplasiás szindróma; MDSC $=$ (myeloid-derived suppressor cells) myeloid eredetü szuppresszor sejtek; MEK = MAPK/ERK kináz; $\mathrm{MHC}=(\mathrm{ma}-$ jor histocompatibility complex) major hisztokompatibilitási komplex; $\mathrm{mTOR}=($ mammalian target of rapamycin $)$ a rapamicin célpontja emlősökben; MTX = metotrexát; NHL = nonHodgkin-lymphoma; NSAID = (nonsteroidal antiinflammatory drug) nemszteroid gyulladáscsökkentő gyógyszer; OPG = osteoprotegerin; $\mathrm{PDl}=($ programmed death $\mathrm{l})$ programozott halál-1; PDGF $=$ (platelet derived growth factor $)$ thrombocytaeredetü növekedési faktor; PDLl = (programmed death ligand 1) programozott halál ligandum-1; PID = primer immundeficientia; $\mathrm{PMR}=$ polymyalgia rheumatica; $\mathrm{RA}=$ rheumatoid arthritis; $\mathrm{RR}=$ daganatrizikó; RS3PE = (relapsing seronegative symmetric synovitis with pitting edema) relabáló szeronegatív szimmetrikus synovitis ödémával; SCID $=$ (severe combined immunodeficiency) súlyos kombinált immunhiány; SLE = szisztémás lupus erythematosus; SLEDAI = (systemic lupus erythematosus disease activity index) a szisztémás lupus erythematosus betegség aktivitási indexe; $S S$ = Sjögren-szindróma; SSc $=$ szisztémás sclerosis; STAA $=$ szolúbilis TAA; STAT3 $=$ (signal transducer and activator of transcription 3) transzkripciós szignálátvivő és aktiváló molekula-3; TAA = tumorasszociált antigén; TENS $=$ (transcutaneous electric nerve stimulation $)$ transzkután elektromos idegstimuláció; TGF $\beta=$ (transforming growth factor-beta) transzformáló növekedési faktor-béta; TIFl = transzkripciós intermedier faktor- $1 ; \mathrm{TNF} \alpha=$ (tumor necrosis factor-alpha) tumornekrózisfaktor-alfa; $\mathrm{T}_{\mathrm{REG}}=$ regulatorikus T-sejt; tsDMARD = (targeted synthetic DMARD) célzott terápia; $\mathrm{VEGF}=($ vascular endothelial growth factor $)$ vascularis endothelialis növekedési faktor; $\mathrm{WHO}=($ World Health Organization) Egészségügyi Világszervezet

\section{Mi az onkoreumatológia?}

A medicinára és az azzal kapcsolatos ismeretekre egyre inkább a multidiszciplináris jelleg jellemző. Mindez kiemelten vonatkozik a reumatológiára és az onkológiára. Ennek fontos szerepe lehet a közös patogenetikai útvonalak megértése, a differenciáldiagnosztika, a konzíliumkérés (teammunka) és a sok esetben a több betegségre egyaránt ható terápiás stratégiák vonatkozásában is (1. ábra) [1-3].

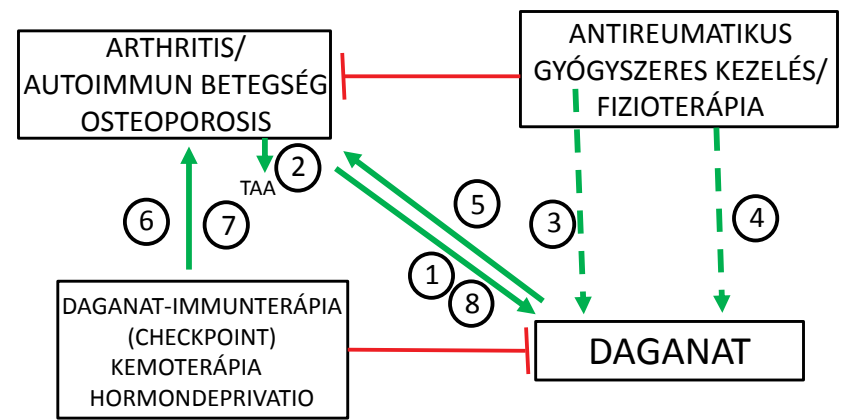

1. ábra

Az onkoreumatológia összefüggései. Az ábrán zölddel a pozitív (serkentő), pirossal a gátló folyamatok látszanak. A reumatológiai kórképekhez szekunder tumorok társulhatnak (1). A gyulladásos kórképeket is kísérheti az adhezív tulajdonságú tumorasszociált antigének (TAA) fokozott termelődése (2). A reumatológiában fóleg korábban alkalmazott gyógyszeres (3) és nem gyógyszeres kezelés (fizioterápia) (4) esetében felmerül a carcinogenitas és a daganat relapsusa, ami miatt óvatosság indokolt. A malignus daganat és az általa termelt mediátorok paraneoplasiás szindrómát okozhatnak (5). A daganat-immunterápia és a kemoterápia autoimmun jelenségeket (6), a hormondeprivatiós kezelés pedig osteoporosist okozhat (7). Végül fontosak a mozgásszervrendszer (támasztószövet) primer és szekunder daganatai is $(8)$ 


\section{1. táblázat $\mid A z$ onkoreumatológia pillérei}

\section{REUMATOLÓGIAI BETEGSÉG $\rightarrow$ DAGANAT}

Szekunder malignitások reumatológiai kórképekben

Szolúbilis tumorantigének reumatológiai betegségekben

Daganatképződés/daganatrelapsus reumatológiai gyógyszeres terápia mellett

Nem gyógyszeres kezelés (fizioterápia) mozgásszervi, daganatos betegben

\section{DAGANAT $\rightarrow$ REUMATOLÓGIAI BETEGSÉG}

Paraneoplasiás szindrómák

Autoimmun/reumatológiai kórképek onkoterápia mellett

Osteoporosis hormondeprivatiós kezelés mellett

A mozgásszervrendszer tumorai

A magyarázatot lásd a szövegben.

Az onkoreumatológia a daganatképződés és a mozgásszervi kórképek találkozását jelenti. Mint látni fogjuk, számos kapcsolódási pont van a két orvosi szakterület között (1.ábra, 1. táblázat). Patogenetikai szempontból több kapcsolódási pont immunológiai mechanizmusokon alapul, így az onkoreumatológia szorosan összefügg az immunonkológiával. Ha e szempontokat megpróbáljuk felosztani, a témák egy része a reumatológiai kórképben szenvedő betegben jelentkező daganatokat, a másik fele pedig a daganatos betegben fellépő mozgásszervi jelenségeket jelenti. Ebben az összefoglalóban, a teljesség igénye nélkül, megpróbáljuk feltérképezni a fóbb kapcsolódási pontokat. Itt most a legjelentősebb, mind a kutató, mind a gyakorló klinikus számára talán legfontosabb témákat érintjük. Mindegyik témáról külön terjedelmes cikket is lehetne írni (bőven elérhetők ilyenek a hazai irodalomban is [4-14]).

\section{Onkológiai kérdések reumatológiai betegségekben}

\section{Szekunder malignitások reumatológiai kórképekben}

Az utóbbi évtizedek kutatásai során derült ki, hogy a reumatológiai betegségekben krónikusan fennálló gyulladás felelős lehet rosszindulatú daganatos betegségek provokálásáért. A modern, hatékony reumatológiai/immunológiai kezelések következtében a kezelt betegek élethossza jelentôsen megnyúlt, így teremtve lehetóséget egy másodlagos malignus betegség kialakulására, akár évtizedek múlva is $[1-3,6,15-18]$.

Röviden, az autoantitest-termeléssel járó reumatológiai kórképekben (például rheumatoid arthritis, RA; juvenilis idiopathiás arthritis, JIA; szisztémás lupus erythematosus, SLE; szisztémás sclerosis, SSc; Sjögrenszindróma, SS; dermatomyositis, DM) a tartós B-sejtstimuláció a betegek egy részében malignus lymphoproliferativ kórkép, leginkább non-Hodgkin-lymphoma (NHL) kialakulásához vezethet $[6,17-23]$. Mindezt az egyidejű Epstein-Barr-vírus (EBV)-fertőzés még fokozhatja [24]. Másrészt, a gyulladás által érintett célszövetekben, célszervekben gyakrabban alakulnak ki szolid tumorok $[1,4]$. RA-ban a lymphomák átlagosan 12-szeres incidencianövekedése figyelhető meg. A szolid daganatok közül a tüdőrák kb. 25\%-kal gyakoribb az átlagpopulációhoz képest: kialakulásában a RA patogenezisében is szerepet játszó dohányzás lényeges. Emlő- és méhnyakrák szintén gyakrabban fordul elő, viszont a colorectalis és gyomorrákok vonatkozásában - valószínúleg a gyulladásgátlók szedése miatt is - alacsonyabb a rizikó $[1,2,6,25]$. SSc-ben a NHL kockázata a tízszeresére nőtt. A szolid tumorok szintén a gyulladás és szöveti fibrosis által leginkább érintett szervekben (tüdő, bőr, nyelőcső) jelentkeznek. Az idősebb kor, a hosszabb betegségfennállás és a tüdőfibrosis jelent komolyabb rizikót a daganatképződés vonatkozásában $[1,3,19,26]$. DMben az emlő-, tüdö- és gyomorrák jelentkezik gyakrabban. Nagyon fontos, hogy a myositishez társuló szekunder daganat nem azonos a daganatokhoz társuló myositis (cancer-associated myositis, CAM) paraneoplasiás szindrómával [1, 3, 27]. SLE-ben a lymphomák, az emlőrák, a tüdőrák és a máj-epeúti rosszindulatú tumorok és bizonyos sarcomaaltípusok incidenciája egyaránt megnövekedett. A NHL kialakulásának az EBV-fertőzés, az idősebb kor és a tartósabb betegségfennállás a rizikótényezője $[1,20,24]$. SS-ben egyértelmúen a lymphoproliferativ kórképek gyakoribbak. SS-ben többek között a lymphadenopathia, az elhúzódó parotitisduzzanat, a vasculitis, a veseérintettség, a fiatalabb életkor, az anaemia és a leukopenia a hajlamosító tényező [1, 17, 22]. Végül, a svéd regiszterben még biológiai terápiával nem kezelt JIA-betegekben is észlelték a malignitásrizikó 2,3-szeres fokozódását. Összesen 9000 JIA-betegból 60 rosszindulatú daganatos esetet találtak [23].

Fontos kérdés a primer immundeficientiák (PID) és a daganatok kapcsolata. A legfontosabb a defektív sejtes immunitás következtében kialakult tumor „immunosurveillance" károsodása, például a súlyos kombinált immunhiány (SCID) eseteiben, amelyekben elsősorban a lymphomák kialakulása a gyakoribb. A PID-hez társuló malignitások kialakulásában szerepe lehet bizonyos infekcióknak, onkogén vírusoknak és egyéb ágenseknek, melyek a krónikus gyulladásos állapot fenntartásával malignus transzformációt idézhetnek elő. Emellett döntő szerepe van az egyes PID-ekhez társuló genetikai mutációknak, melyek a genetikai instabilitás révén vesznek részt a tumorképződésben. A DNS-repair károsodása figyelhető meg ataxia teleangiectasiában (AT) és vagy Bloom-szindrómában, az apoptózis zavara autoimmun lymphoproliferativ szindrómában (ALPS), a sejtciklusban szereplő checkpoint kiesése porc-haj hypoplasiában. Wiskott-Aldrich-szindrómában a cytokinesis defektusa következtében genetikailag instabil tetraploid sejtek alakulnak ki. Irodalmi adatok szerint a PID-es betegek 4-25\%-ában alakul ki malignus megbetegedés [28]. 
Spondylarthritisekben (SpA; spondylitis ankylopoetica és arthritis psoriatica) az RA-val ellentétben nem észlelték az alapbetegség következtében kialakuló lymphomák vagy szolid tumorok kialakulásának fokozott rizikóját [1, 29].

Saját anyagunkban, az utolsó felmérés alkalmával, 516 RA-beteg közül 13 esetben alakult ki malignus daganat. Ebből 6 tüdőrák volt [6]. SSc-s betegeink között 218 SSc-s beteg közül 11 esetben alakult ki rosszindulatú tumor, elsősorban B-NHL és tüdőrák [6]. SLE-ben 860 vizsgált betegből 37 esetben alakult ki daganat. A leggyakoribb (1l eset) az emlőrák volt. A daganatos esetek mintegy kétharmadában a betegek megelőzően carcinogen hatásáról ismert azatioprint (AZA) vagy ciklofoszfamidot (CYC) kaptak (lásd később) [20]. A katasztrofális antifoszfolipid-szindróma (CAPS) az APS súlyos, gyakran halálos variánsa. Két ilyen esetünkben endometrium- és gyomorrák mellett alakult ki CAPS [1, 30]. Végül, egy korábbi felmérésben, azt vizsgáltuk, hogy a lymphomások között milyen gyakran fordulnak elő autoimmun betegek. A 421 gondozott NHL-betegból 32-nek volt autoimmun betegsége, a leggyakrabban SS. Az 519 Hodgkin-kóros (HK) betegből 45 esetben igazolódott autoimmun háttér [21].
Ami a sejtes és molekuláris patogenezist illeti, röviden, a krónikus gyulladás genotoxicitás, kóros szöveti repair, fokozott sejtproliferációs aktivitás, tumorinvázió és metastasisképzés révén vezet daganatképződéshez és -terjedéshez (2. ábra) $[15,16]$. Érdekes kérdés, hogy amikor az akut gyulladás krónikussá válik, az utóbbi miért nem a gyulladáscsökkenés irányába halad. A gyulladást kiváltó stimulusok perzisztenciája és neuroendokrin eltérések is fenntarthatják az idült gyulladást. Ezt követően pedig, többek között, a mutációk, az apoptózis defektusa, növekedési faktorok, fokozott angiogenezis, hormonális és epigenetikus (környezeti) faktorok is szerepet játszhatnak a krónikus gyulladás daganatirányú transzformációjában [16]. Direkt összefüggés van a gyulladásos aktivitás és a malignitásrizikó között $[6,31]$. Szisztémás autoimmun-reumatológiai kórképekben az autoantitestperzisztenciának is komoly szerepe lehet: SSc-ben az autoantitest-szeropozitivitás kedvezőtlenebb daganattúléléssel jár együtt $[19,32]$.

A gyulladásos sejtek közül a myeloid elemek (monocyta/macrophagok) által termelt proinflammatorikus citokinek (tumornekrózisfaktor-alfa [TNF $\alpha$ ], interleukin-1 [ILl] és IL6) gátolják az epithelsejtek érését, és serkentik az epithel-mesenchymalis átalakulást. Az utóbbit a

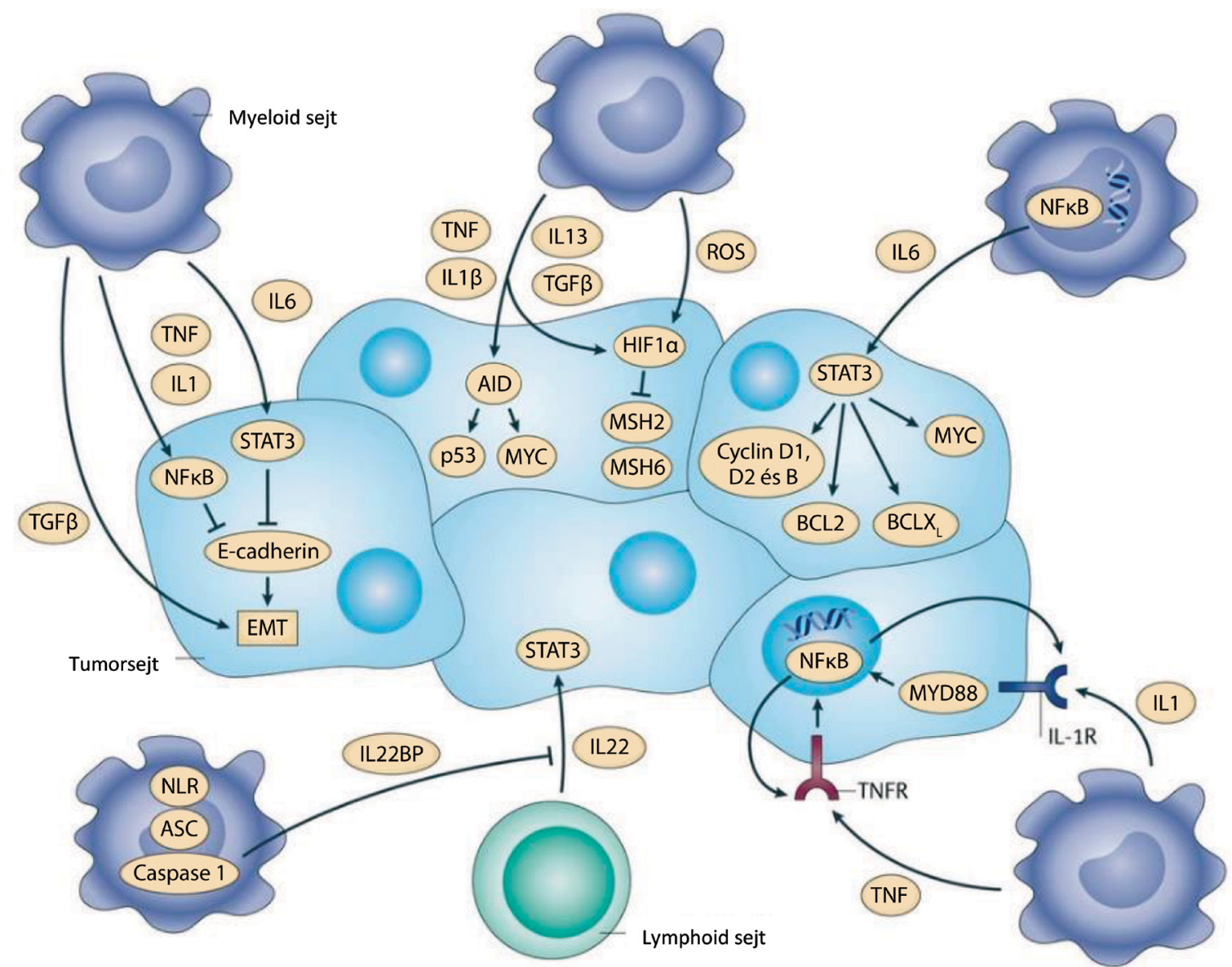

2. ábra Szekunder daganatképződés reumatológiai kórképekben. Az immunsejtek által termelt mediátorok serkentik bizonyos daganatgének átíródását, és kedveznek a daganatnövekedésnek. További magyarázat a szövegben ([15] alapján)

IL = interleukin; $\mathrm{NFkB}$ = nukleárisfaktor-kappa-B; TGF $\beta$ = transzformáló növekedési faktor-béta; TNF = tumornekrózis-faktor 


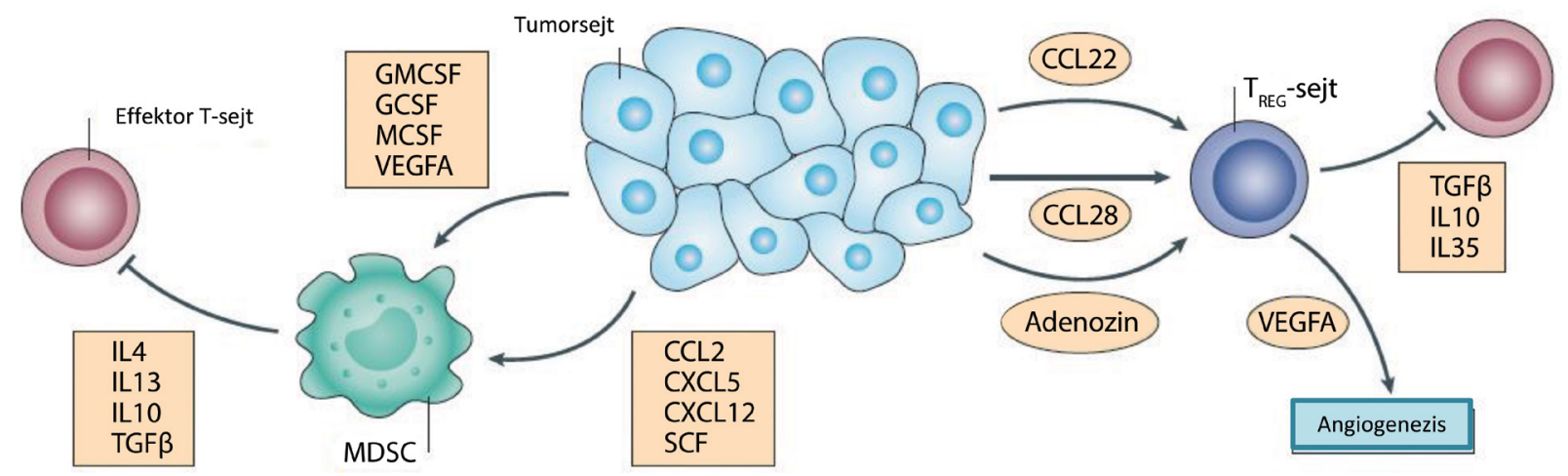

3. ábra
A daganat visszahatása az immunsejtekre és a da További magyarázat a szövegben ([15] alapján)
$\mathrm{IL}=$ interleukin; TGF $\beta$ = transzformáló növekedési faktor-béta

transzformáló növekedési faktor-béta (TGFß) közvetlenül is stimulálja. A TNF $\alpha$, ILl, IL13 és TGF $\beta$ egyrészt a p53 és Myc onkogének expresszióját, másrészt a hypoxiaindukált faktor-1-alfa $(\mathrm{HIFl} \alpha)$ stimulációja révén a tumor-angiogenezist serkentik. Az IL6 a STAT3 aktivációján keresztül egyéb onkogének expresszióját is növeli (2. ábra) $[15,33]$.

A kialakult tumorok, visszahatva, átalakítják a gyulladásos szöveti környezetet (3. ábra). Elsősorban szolúbilis növekedési faktorokat és kemoattraktánsokat termelnek, amelyek végső soron a tumorellenes T-sejtes immunreakciókat gátolják, ami kedvez a daganatnövekedésnek. A daganatellenes $\mathrm{T}_{\mathrm{H}} \mathrm{l}$-sejtek helyett immunszuppresszív regulatorikus T-sejtek $\left(\mathrm{T}_{\mathrm{REG}}\right)$ szaporodnak fel. A macrophagok fenotípusa a proinflammatorikus Ml felől az M2 irányába tolódik át. Emellett pedig myeloid eredetú szuppresszor sejtek (myeloid-derived suppressor cells, MDSC) képződnek [15, 16, 33]. Összességében a daganatsejtek a tumorellenes gyulladásos reakció átprogramozásával visszaszorítják a daganatellenes védekezést (3. ábra) $[15,16]$.

Külön szóljunk a „B-sejtes” betegségekben kialakuló lymphomák patogeneziséról. Az autoimmunitásból a daganat irányába történő átalakulásában genetikai tényezők (apoptózisgének, génpolimorfizmusok, MHCallotípus, enzimdefektusok), környezeti tényezők (fertőzések, szövetsérülések, gyógyszerek, vegyszerek) és immunológiai eltérések állnak. Az utóbbiakra jellemző, hogy a szekunder immundeficientia, a $\mathrm{T}_{\mathrm{REG}}$-sejtek defektusa, a $\mathrm{T}_{\mathrm{H}} 1 / \mathrm{T}_{\mathrm{H}} 2$ arány megváltozása, a citokinek túltermelődése, a kostimulációs antigének fokozott expressziója mind szerepet játszanak. Mindez például SS-ben az epithelium károsodásához (apoptózis, csökkent repair, proteolysis) vezet. A B-sejtes autoimmunitás és a lymphomák patogenezisében fontos szerepet játszik a B-sejtaktiváló faktor (BAFF)/A Proliferation Inducing Ligand (APRIL) rendszer. Ez mint checkpoint ugyancsak részt vesz a centrális és perifériás immuntoleranciában. Egyrészt csökkent múködése kedvez a „B-sejtes” kórképek kialakulásának, másrészt a túlzott BAFF/APRIL ex- presszió a poliklonális, majd monoklonális folyamatok kialakulásának. Nem véletlen, hogy a BAFF-gátló belimumab bevethető mind autoimmun kórképekben (c), mind B-sejtes lymphomákban [17, 18, 21, 22].

Mint újabban kiderült, az esetek 20\%-ában a mikrobiom is szerepet játszik e folyamatokban. Humánvizsgálatok valószínúsítették a Helicobacter pylori mellett az Escherichia coli, valamint egyes Fusobacterium- és Bacteroides-fajok szerepét a gyulladásos bélbetegséghez kapcsolódó vastagbélrák patogenezisében. Valószínúleg a reumatológiai kórképekben is hasonló folyamatok játszódnak le [34].

\section{Szolúbilis tumorantigének reumatológiai betegségekben}

A napi laboratóriumi diagnosztikában is használatos $\mathrm{c}-\mathrm{k}$ jelennek meg a betegek vérében, ami a diagnosztika alapját képezi.

Néhány évtizeddel ezelőtt kiderült, hogy a TAA-k a tumorsejtek mellett gyulladásos leukocyták felszínén is megjelenhetnek. Magunk elsők között mutattuk ki a c-k magasabb vérszintet mutathatnak bizonyos gyulladásos, autoimmun megbetegedésekben [3].

Korábbi kutatásaink során több TAA szérumszintjét határoztuk meg RA-ban, SSc-ben és SLE-ben. Több RA-betegben volt kórosan emelkedett CA125, CA19-9 és CAl5-3 a kontrollokkal összevetve. Több SSc- és SLE-betegnél volt abnormisan magas a CEA, CA19-9, CA125, CA72-4 vagy CAl5-3 értéke a kontrollokhoz képest. SSc-ben több sTAA korrelált a veseérintettséggel, arthritisszel és a CRP-vel, míg SLE-ben a sTAAszintek korreláltak a központi idegrendszeri manifesztációval és a SLEDAI indexszel [3].

A napi gyakorlat számára az a tanulság, hogy autoimmun-gyulladásos reumatológiai betegekben a sTAA vérszintjének mérését nagy óvatossággal kell végezni és értékelni. Minimális TAA-emelkedés lehet a gyulladásos alapbetegség következménye [3]! 


\section{Daganatképzödés/daganatrelapsus reumatológiai gyógyszeres terápia mellett}

A kérdés az, hogy a tirozin-kináz-gátlók fokozzák-e a daganatrizikót $[1,35]$. A kérdést komplikálja, hogy - mint láttuk - a szisztémás gyulladás önmagában is teret enged a tumorképződésnek [1,31], így nem egyértelmü, hogy végső soron a kialakult daganatért az alapbetegség vagy az alkalmazott kezelés tehetō-e felelőssé. Ezt a kérdést a nagy regiszterekben végzett sorozatos elemzések válaszolhatják meg, melyek során időben összevetik az évtizedekkel ezelőtti adatokat a mostaniakkal $[1,31,35-$ 37].

CYC-ot, AZA-t és ciklosporin A-t (CsA) arthritisekben ma már csak nagyon ritkán, inkább szisztémás vasculitisekben, SSc-ben, SLE-ben, IIM-ben használnak. Az Egyesült Királyság nagy regiszterében végzett többszörös regressziós analízis alapján az AZA, CYC vagy CsA szedése esetén a daganatrizikó (RR) 1,63 (95\% CI: $1,05-2,52)$ volt $[35,36]$.

A reumatológiában legszélesebb körben alkalmazott csDMARD a kis dózisú metotrexát (MTX), mely irodalmi áttekintés alapján nem emeli a malignitások kialakulásának rizikóját $[1,35]$. Korábban, a biológiai terápia bevezetése (2016) előtt növekedni látszott MTX-terápia mellett egyes rosszindulatú hematológiai kórképek incidenciája, de ma már valószínúsíthető, hogy ez az EBVpozitivitással magyarázható inkább, mintsem a MTX adásával $[1,35]$.

A biológiai terápiák (bDMARD) esetében van különös jelentősége annak, hogy a felmérést mikor végezték. Az első nagy, 2006-ban végzett svéd felmérésben, összesen hét, 2000 és 2004 közötti vizsgálat metaanalízise szerint az RR 3,29 (95\% CI: 1,19-9,08) volt, vagyis a biológiai terápia összességében háromszoros rizikót jelentett [31]. Tudni kell azonban, hogy hazánkban is csak azokban az években kezdték el adni a bDMARD-okat. Ebben az idôben még nem a korai, hanem a hosszú betegség-fennállású, más gyógyszerekre refrakter betegek kaptak bDMARD-kezelést, akik amúgy is esendőbbek voltak daganat szempontjából [31]. Ahogy az időben haladva újabb és újabb felmérések kerültek napvilágra, úgy csökkent, majd túnt el a daganatrizikó-emelkedés $[1,35]$. 2017-ben a svéd regiszterben és több más tanulmányban már az akkor elérhető összes bDMARD-ról (öt TNF-gátló, rituximab, tocilizumab, abatacept) szolgáltattak adatokat. Összességében egyik bDMARD esetében sem tapasztaltak emelkedett daganatrizikót (első szolid vagy lymphoproliferativ daganat) [36]. Időben ezután jelentek meg a célzott szintetikus tsDMARD-ok, először a Janus-kináz (JAK)-gátló tofacitinib és baricitinib. A daganatrizikó a fázis III. vizsgálati programot és a posztmarketingadatokat figyelembe véve egyik JAK-gátló esetében sem volt magasabb a bDMARD-okhoz képest [37].
Összességében tehát, a régebbi típusú csDMARDszerekkel (AZA, CYC, CsA) ellentétben sem a MTX, sem a bDMARD és a tsDMARD célzott terápiák a mostani időkben nem emelik a daganatrizikót, sem az új tumorok megjelenését, sem a relapsust [1,35-38].

\section{Nem gyógyszeres kezelés (fizioterápia) mozgásszervi, daganatos betegben}

A fizioterápia, elsődlegesen a gyógytorna lényegében hidat képez két nagy tématerületünk között. Ez esetben ugyanis egyrészt az a kérdés, hogy a reumatológiai beteg kaphat-e fizioterápiát, ha daganata is van/volt, és ez mennyire lehet veszélyes a daganatképződés szempontjából. Másrészt a fizioterápia a daganatos betegség szempontjából is kedvező hatású lehet [14, 39]. Az utóbbi 10-20 évben, a daganatos anamnézis abszolút kontraindikációt jelentett fizioterápiás rehabilitáció szempontjából. Ez a szemlélet, mint látni fogjuk, alapvetôen megváltozott $[14,39]$.

A daganatos betegek fizioterápiájának kérdéskörét egyszerúbb megválaszolni. Összesen 34 nagy tanulmány metaanalízise alapján a gyógytorna jelentősen javítja a daganatos betegek fizikai funkcióját és életminőségét [39].

Amennyiben a mozgásszervi alapbetegség kezelése az elsődleges az egyébként daganatos vagy daganaton átesett betegben, a kezelés egyéni mérlegelést igényel. Minden esetben mérlegelni kell az egyéni haszon/kockázat arányt. Az e témában végzett klinikai kutatások értéke igen eltérő. A legmagasabb evidenciával a gyógytorna tárgykörében közölt vizsgálatok bírnak. Elsősorban az aerob mozgásformák javasoltak a betegek számára, melyek különböző kóros állapotok (például a fájdalmakból eredő hangulatzavarok, krónikusfáradtság-szindróma, alvászavar stb.) mérséklésén, valamint az általános izomerő és kondíció fokozódása révén javítják az életminőséget. Az egyéb fizioterápiás modalitások közül bizonyos masszázskezelések (például emlőrákosok nyirokmasszázsa) és elektromos kezelések (például TENS) vonatkozásában megengedőbbek a vélemények, bár magas evidenciájú vizsgálatok e témában sem érhetôk el. Emlorrákos betegek mútét utáni rehabilitációjában a hidroterápia igen hatékony és biztonságos volt. Szigorúbbak a feltételek a balneoterápiát, az ingeráram-kezeléseket és az ultrahang-terápiát illetően. Természetesen az ingeráram-kezelés fontos lehet a legyengült izomzat kezelésére, a balneoterápiát pedig egyre többet alkalmazzák az onkológiai rehabilitációban. Néhány kezelés (például rövidhullám-kezelés, hőterápia, illetve galvánáram-kezelés) daganatos alapbetegség esetén ellenjavallt, mivel a tumorszövet keringését is javítva, kedvezhet a daganat szóródásának [14, 39].

A kemény evidenciák hiányában tehát minden betegnél a legfontosabb az előny/kockázat arány mérlegelése, és a társszakmák közötti szoros együttmúködés [14, 39]. 


\section{Mozgásszervi jelenségek a daganatos betegben}

\section{Paraneoplasiás szindrómák}

A paraneoplasiás szindróma a daganat távoli hatása következtében alakul ki. A daganat, hasonlóan ahhoz, ahogy a gyulladásos mikrokörnyezetben viselkedik (lásd előbb), hormonokat, citokineket, peptideket, antitesteket termel, ami a szervezet egy másik pontján mozgásszervi tünetegyüttest vált ki. A szolúbilis mediátorok mellett sejtes reakciók (például citotoxikus T-sejtek) is kiválthatnak ilyen jelenségeket $[4,5,40]$. A paraneoplasiás mozgásszervi szindrómákra jellemző, hogy általában évekkel az onkológiai diagnózis előtt lehetnek a betegnek gondozást igénylő, lassú progressziójú, általában aszimmetrikus panaszai, melyeket antireumatikus terápi- ával kezelnek. Nemegyszer annak hatástalansága és egyéb, daganatra utaló általános tünetek (láz, fájdalom, általános és izomgyengeség, fogyás, fáradékonyság) vetik fel egyéb, esetleges malignus betegség lehetőségét a háttérben (4. és 5. ábra) [2, 4, 5, 40]. Ugyancsak fontos, hogy a paraneoplasiás jelenségek a daganat eltávolítása, remissziója esetén csillapodnak, a tumor relapsusa esetén kiújulhatnak $[4,5,40]$.

A paraneoplasiákat a 4. ábrán bemutatott csoportokra oszthatjuk. A klinikai tünetcsoportok ennek megfelelően lehetnek arthritisek, szisztémás autoimmun kötőszöveti szindrómák, vasculitisek, bőr- és izombetegségek, anyagcsere-betegségek. A felsorolt paraneoplasiák nagyon hasonlítanak a megfelelő kórképre. De a „RA-like”, „lupusszerü” vagy „cancer-associated myositis” jelleg arra utal, hogy nem teljes mértékben felelnek meg a klasszikus megfelelő betegségeknek [4, 5, 40]. Röviden jelle-
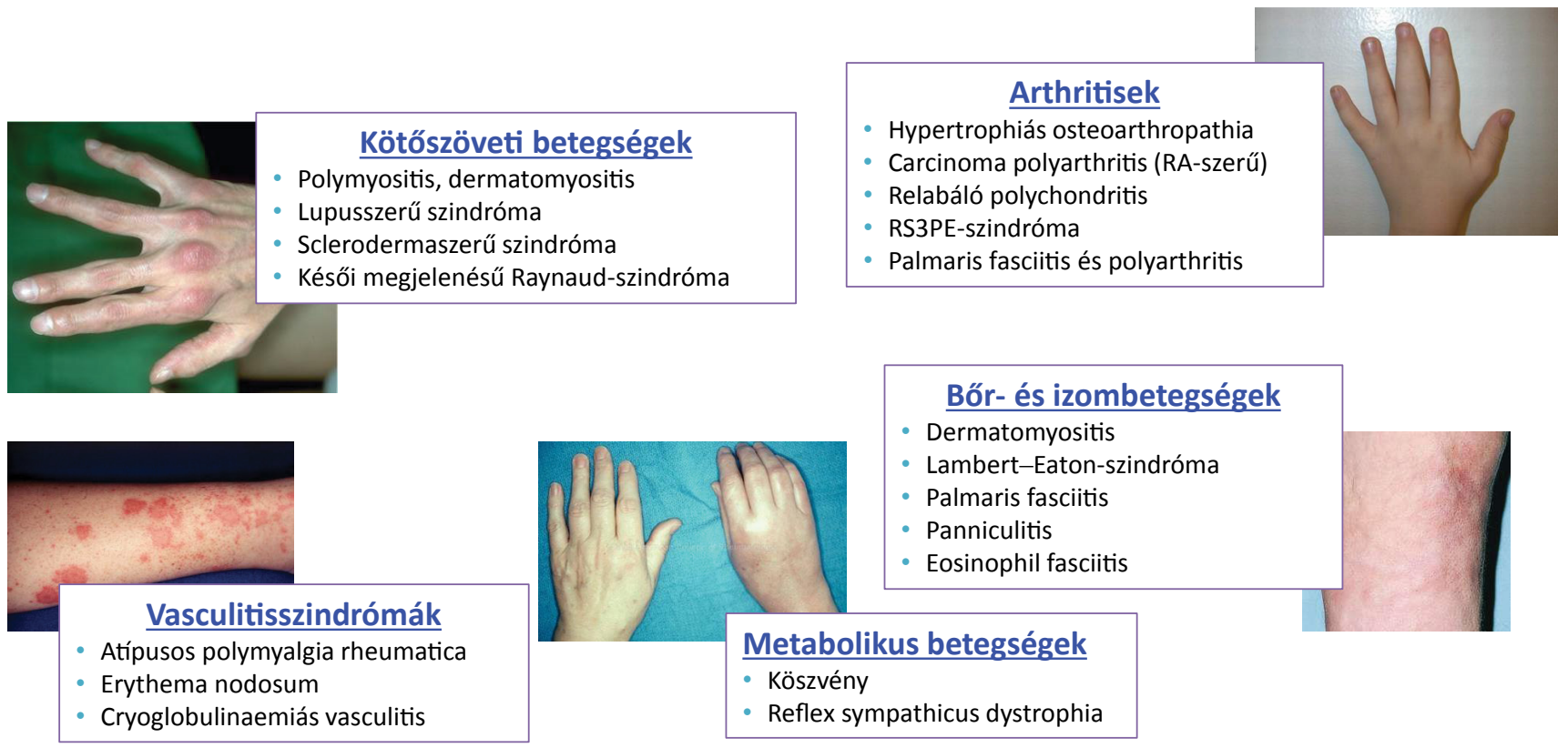

Bőr- és izombetegségek

Dermatomyositis

Panniculitis

\section{Metabolikus betegségek}

- Reflex sympathicus dystrophia

\begin{tabular}{l|l} 
4. ábra & $\begin{array}{l}\text { Paraneoplasiás szindrómák. Főbb csoportok és kórképek. További magyarázat a szövegben } \\
\text { RA = rheumatoid arthritis; RS3PE = relabáló szeronegatív szimmetrikus synovitis ödémával }\end{array}$
\end{tabular}
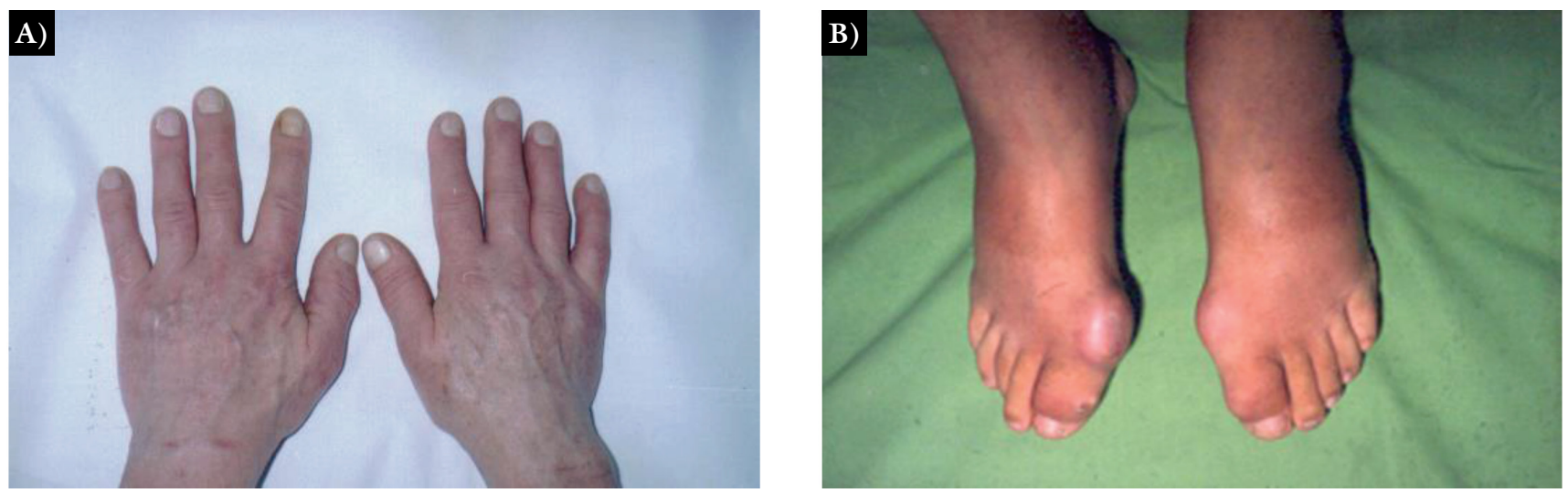

Klinikai példák paraneoplasiára. (A) Egy 49 éves nőbetegünk ductalis emlőrákja következtében kialakult RA-szerű (carcinoma) polyarthritis. (B) Egy 47 éves, végbél- és veserákban szenvedő betegünkben jelentkező szekunder köszvény 
mezve a fóbb reumatológiai paraneoplasiákat, a kötőszöveti betegségek közül a már említett CAM - amely nem azonos a myositisekhez társuló szekunder tumorokkal gyakrabban jelentkezik DM, mint PM képében, általában 50 éves életkor felett. Saját beteganyagunkban a 43 CAM-betegből 15 emlőrákos és 12 tüdőrákos volt. A klasszikus DM-hez képest súlyosabb bőrtünetek és a rekeszizom érintettsége jellegzetes. A lupusszerú szindróma emlö-, petefészekrákhoz, mesotheliomához és hajas sejtes leukaemiához (HCL) szokott társulni a leggyakrabban. A sclerodermaszerü betegség a tüdő-, emlő- és petefészekrák mellett jelentkezik, és az antitopoizomeráz I (anti-Scl70) antitest pozitivitása jellemzi. A polymyalgia rheumatica (HCL-hez) ebben az esetben fiatalabb korban (<50 év), aszimmetrikusan jelentkezik, és a szisztémás gyulladás sem annyira kifejezett, mint a klasszikus PMR-ben. A paraneoplasiás erythema nodosumban a szokottnál tartósabban (>6 hét) fennmaradnak a tünetek. Ez a forma kortikoszteroid-kezelésre refrakter. Leukocytoclasticus vasculitis jelentkezhet myelodysplasiás szindrómákban (MDS) és lymphoproliferativ kórképekben is. Az arthritisek közül a RA-szerü „carcinoma polyarthritis" a szokottnál idősebb életkorban jelentkezik. Progressziója a klasszikus RA-nál gyorsabb, aszimmetrikus, és alsó végtagi dominancia jellemzi. Általában szeronegatív. A hypertrophiás osteoarthropathia (HOA) a paraneoplasia-patogenezis egy jó példája, melyet később tárgyalunk. A jellegzetes dobverőujj periostealis proliferáció miatt alakul ki. Tüdőrák vagy pleuralis mesothelioma okozhatja. Az RS3PE-szindróma (relapsing seronegative symmetric synovitis with pitting edema) ido"sebb férfiakban lép fel. A kezek, lábak érintettsége, szeronegativitás, de jellegzetes szisztémás gyulladás jellemzi. A rekurrens polychondritis az orr-, fülporcok, tracheobronchialis traktus porcszövetének és az ízületi porcnak a gyulladásával jár. MDS állhat a háttérben. A palmaris fasciitis a tenyér duzzanatával, melegségével, pirosságával jár, Dupuytren-kontraktúrát utánozhat. Az eosinophil fasciitis a sclerodermaszerú kórképek közé tartozik. Kézfájdalom, fasciitis, eosinophilia jellemzi kontraktúra kialakulása nélkül. A másodlagos hyperuricaemia és köszvény disszeminált szolid tumorokhoz, lymphoproliferativ kórképekhez és azok kemoterápiájához társul. Az algodystrophia paraneoplasiás formája tüdő-, petefészek-, hasnyálmirigyrák megjelenése lehet. A kültakaró paraneoplasiái között megemlítendő a panniculitis is $[4,5,27,40]$. Két klinikai esetünket az 5. ábra mutatja be.

Ami a sejtes és molekuláris patogenezist illeti, klasszikus példa a már említett HOA. A dobverőujj a tumor által termelt angiogén mediátorok, elsősorban a c- és thrombocytaeredetű növekedési faktor (PDGF) neovascularisatiót stimuláló hatásából ered. Ennek következtében a lágyrészek ödémásak lesznek, szöveti fibrosis alakul ki, és a periosteum megvastagodik, ami a jellegzetes klinikai képet okozza [40]. A CAM a tumor által termelt TIFl-antitest révén okoz izomgyulladást. Végül, a stroma mesenchymalis sejtjei által termelt fibroblastnövekedési faktor 23-at (FGF23) termelnek, amely a vesében fokozza a foszfátürítést, ezáltal osteomalaciát okozva $[5,6,40]$.

\section{Autoimmun/reumatológiai kórképek onkoterápia mellett}

\section{Hagyományos (szintetikus) kemoterápiás szerek és citokinek}

Már a hagyományos kemoterápiás szerek mellett is tapasztalhatók reumatológiai jellegú mellékhatások. A mozgásszervi tünetek általában a kemoterápia után néhány héttel vagy hónappal jelentkeznek. A panaszok (arthralgia, myalgia, reggeli ízületi merevség, a kézkisízületek, bokák, térdek periarticularis duzzanata) rendszerint nem gyulladásos jellegüek, migrálóak, és egy év alatt maguktól elmúlnak („self-limiting”). Nem erozív jellegüek, és NSAID-re jól reagálnak. A leggyakrabban a CYC, az 5-fluorouracil (5-FU), a tamoxifen, a MTX és a ciszplatin okoz ilyen komplikációkat. A bleomicin, a Vinca-alkaloidák és a platinaszármazékok Raynaudszindrómát, az 5-FU, a ciszplatin, a CYC, a MTX, az aromatázgátlók és a tamoxifen arthralgiát, myalgiát okozhatnak. Az aromatázgátlók és antiandrogének osteoporosist okozó hatásáról később külön fejezetben szólunk. A citokinek és a citokingátló biologikumok közül az interleukin-2 (IL2) arthralgiát, myalgiát, az IN pedig RA- vagy SLE-szerú klinikai képet válthat ki. A kinázgátlók közül a BRAF- és MEK-inhibitorok az esetek összesen 40\%-ában okoznak enyhe, közepes vagy súlyos ízületi fájdalmat $[1,2,7]$.

\section{Immuncheckpointgátlók (immunterápia)}

Az Orvosi Hetilap hasábjain a közelmúltban részletes összefoglalót közöltünk ebben a témában [7], ezért most csak általános áttekintést adunk. Az immunellenőrző pontok - más néven „immuncheckpointok” - az immunrendszer aktivációjának szabályozó fehérjéi. Az immunreakció - jelen esetben a tumorellenes immunitás - kezdeti alapvető lépése, amikor az antigénprezentáló sejtek (APC; például dendritikus sejtek, DC; macrophagok) a (tumor)antigént bemutatják a T-sejtnek. Ezt követően a T-sejt felismeri és - optimális esetben - elpusztítja a tumorsejtet. Ismeretes, hogy az antigénfelismerés során a leírt elsődleges felismerési mechanizmus mellett egy második, ún. kostimulációs szignál is szükséges a folyamathoz. Amennyiben az APC B7-1 antigénje a T-sejt CD28-as molekulájához kötődik, pozitív szignál (kostimuláció) jön létre, és a T-sejt aktiválódik. Ha azonban az APC-n levő B7-2 molekula a T-sejt CTLA4-antigénjével vagy az APC programmed death ligand-1 (PDLl-) molekulája a T-sejt PDl-receptorával kapcsolódik, negatív, gátló szignál (koinhibíció) jön létre, és T-sejt-anergia alakul ki (6. ábra). Ha tehát a tumort elpusztítani készülő T-sejt PDl-receptora a daganatsejt PDLl-ligandjához kapcsolódik, koinhibíció jön létre, és a T-sejt nem képes 
A

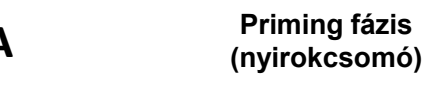

B
Effektorfázis

(perifériás szerv/szövet)

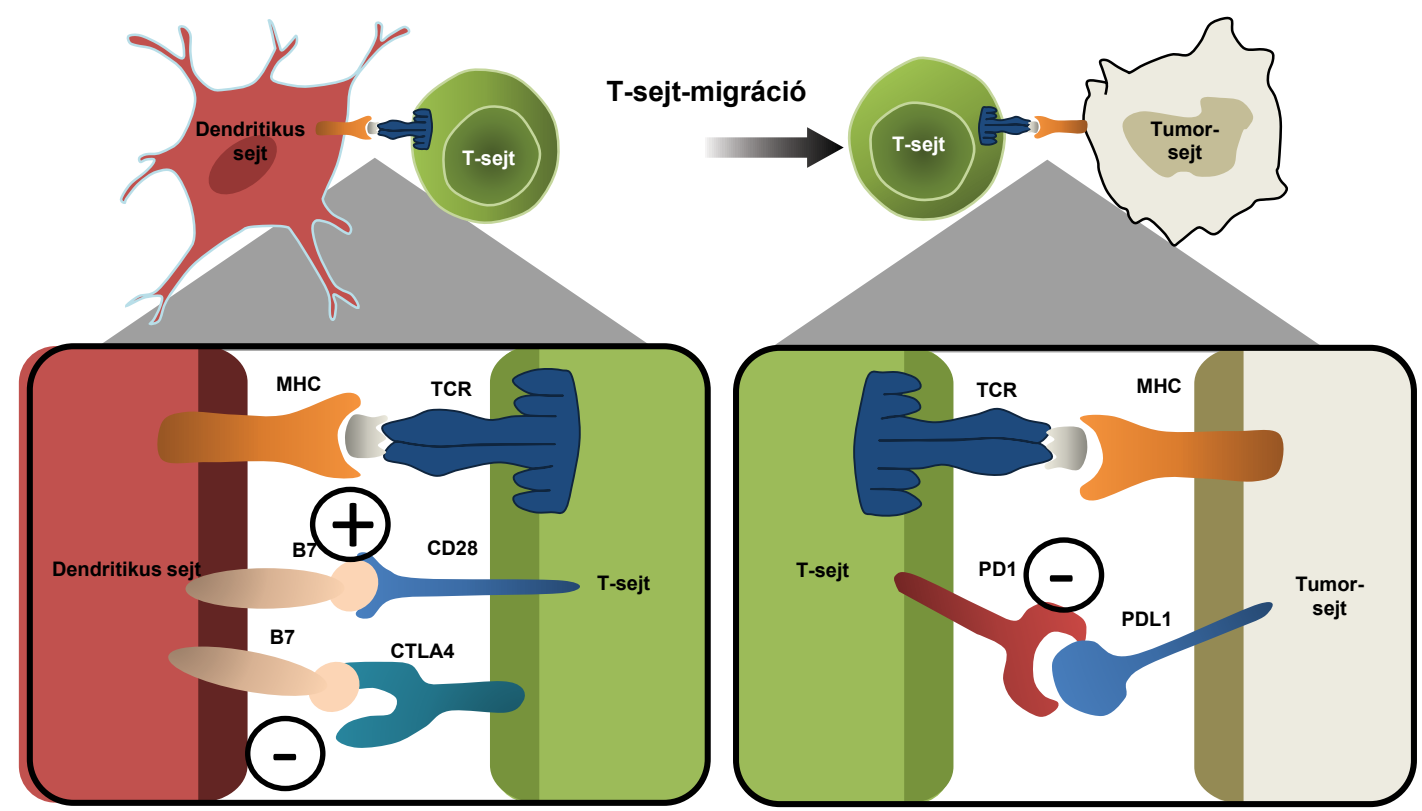

6. ábra

\begin{abstract}
Az immuncheckpointok részvétele a daganatellenes immunitásban. (A) Az elókészítő (priming) fázisban a nyirokcsomókban a T-sejt „tanulási fázison” megy keresztül. Az antigénprezentáló dendritikus sejtek (DC) a tumorantigént bemutatják. Az ismert T-sejt-receptor-MHC kapcsolódás mellett kostimulációra is szükség van. Ha a pozitív B7-CD28 kapcsolódás alakul ki, az antigénfelismerés létrejön. A CTLA4-B7 kapcsolódás viszont koinhibíciót és következményes immuntoleranciát vált ki. (B) A „tanult” T-sejtek a perifériás (tumor)szövetbe vándorolva beindítják a tumor elleni védekezést. A PDl-PDLl kapcsolódás azonban szintén koinhibíciót jelent, ami gyengíti a T-sejtes antitumorválaszt. Bővebb magyarázat a szövegben ([41] alapján)

CTLA = citotoxikus-T-lymphocyta-antigén $; \mathrm{MHC}=$ major hisztokompatibilitási komplex $; \mathrm{PDI}=$ programozott halál-1; PDLl = programozott halál ligandum-1; TCR = T-lymphocyták receptora
\end{abstract}

tovább kontrollálni a tumorprogressziót [7, 41, 42]. A koinhibíciót gátló, ezáltal a tumor elleni védekezést javító CTLA4, PDl vagy PDLl elleni monoklonális antitesteket hívjuk immuncheckpoint-inhibitoroknak (ICI) $[7,41]$. A jelenleg törzskönyvezett ICI-k közé tartozik a CTLA4-gátló ipilimumab, a PDl-gátló nivolumab és pembrolizumab, valamint a PDLl-gátló atezolizumab, avelumab és durvalumab. E gyógyszerek és más daganatellenes szerekkel történő kombinációik indikációi közül kiemelendő a metastaticus melanoma és a tüdőrákok, de fej-nyaki laphámrákok, máj-, vese-, húgyhólyagrák, illetve Hodgkin-kór kezelésében is egyre szélesebb körben érhetők el, ma már hazánkban is [7-11, 41, 43].

$\mathrm{Az}$ ICI-k mellékhatásprofilja teljesen eltér az eddig megszokott, „klasszikus” kemoterápiák és célzott kezelések okozta jelenségektől (2. táblázat). Mivel az ICI-k célpontja nem a daganatsejt maga, hanem a gazdaszervezet immunrendszere, az egyre gyakrabban felismert autoimmun mellékhatások a védekezőrendszer aktiválódása következtében jönnek létre (összefoglalók: [7, 4346]).

Ami a molekuláris mechanizmusokat illeti, az ICI-k számos intracelluláris szignálútvonalat befolyásolnak (7. ábra). A PDl-és PDLl-stimuláció hatására gátlódik az mTOR- (sejtnövekedés és fehérjeszintézis), a Bcl-xL(sejttúlélés) és a Ras- (sejtproliferáció) szignál átvitele. Emellett anyagcsere-változások (a glycolysis gátlása és a zsírsavanyagcsere fokozódása) is bekövetkeznek. Az ICI-k ezeket visszafordítva stimulálják a tumorellenes immunválaszban részt vevő T-sejtek növekedését, proliferációját, túlélését. Emellett a T-sejt-anyagcserét is áttolják olyan irányban, hogy javul az effektori funkciójuk. En-

\begin{tabular}{l|lr} 
2. táblázat & $\begin{array}{l}\text { Reumatológiai betegségek elófordulási } \\
\text { checkpointgátló kezelés mellett }[7,43]\end{array}$ \\
\hline Gyógyszer & Autoimmun kórkép & Gyakoriság \\
\hline CTLA4-gátló & Arthralgia és arthritis & $5-16 \%$ \\
& Myalgia és myositis & $2-18 \%$ \\
& Siccaszindróma & $3-4 \%$ \\
& Xerophthalmia & $3-4 \%$ \\
\hline PDl-gátló & Xerostomia & $7 \%$ \\
\hline & Arthralgia és arthritis & $5-16 \%$ \\
& Myalgia és myositis & $2-18 \%$ \\
& Siccaszindróma & $3-11 \%$ \\
\hline Kombinált kezelés & Xerostomia & $3-11 \%$ \\
\hline & Arthralgia és arthritis & $10,5 \%$ \\
& Myalgia és myositis & $1 \%$ \\
& Siccaszindróma & $3-4 \%$ \\
& Xerostomia & $3-4 \%$
\end{tabular}

CTLA = citotoxikus-T-lymphocyta-antigén; PD = programozott halál 
nek következtében tehát az ICI-k serkentik a tumorellenes immunválaszt, de egyúttal az autoimmun folyamatokat is $[41,42] . \quad \mathrm{Az}$ autoimmun mellékhatások tekintetében alapvető a $\mathrm{T}_{\mathrm{H}} 17 / \mathrm{T}_{\mathrm{REG}}$ egyensúly eltolódása a $\mathrm{T}_{\mathrm{H}} 17$ irányában, valamint egyes autoantitestek és proinflammatorikus citokinek (TNF $\alpha$, IL1, IL6, IL17, interferon- $\gamma$ ) fokozott termelődése (7. ábra) [7, 34, 4244]. Preklinikai állatmodellekben a PDl-gén hiánya vagy a PDI és PDLl gátlása fokozta különböző típusú arthritisek, az SLE, az arthritis, a cardiomyopathia és az autoimmun diabetes kialakulását $[7,42,44]$. Emberi gyulladásos reumatológiai betegségekben, így RA-ban, PsA-ban a PDI és PDLl fokozott expressziója mutatható ki az egészségesekhez képest, ami nyilvánvalóan ellenreguláló, a már elindult autoimmunitást gátló mechanizmus [7, 42, 44]. Következésképpen az ICI-k alkalmazása visszaszorítja ezt az ellenregulációt, ami az autoimmuni- tásnak kedvez [47]. Végül meg kell említeni, hogy a CTLA4- és a PDI/PDLl rendszer mellett megjelentek az újabb koinhibíciós molekulák (például TIM3, LAG3, TIGIT, BTLA, VISTA), melyek ellen szintén fejlesztenek ICI-ket [45].

Ami a humánklinikumot illeti, az ICI mellékhatásainak előfordulása sokkal ritkább, mint a hagyományos citotoxikus kezeléseké (2. táblázat). Jellegzetes, hogy viszonylag hamar, a kezelés indítása után már a kezelés első 3 hónapjában kezdődnek [7, 42, 44]. A különböző autoimmun mellékhatások gyakoriságát a 2 . táblázat foglalja össze [7, 43]. Összességében a szövődmények csaknem valamennyi szervet érinthetik, beleértve a mozgásszervi (arthritis, myositis), légző- (pneumonitis), gastrointestinalis (colitis), endokrin szerveket (pajzsmirigy, hypophysis, diabetes), az idegrendszert (polyneuropathia, demyelinisatio, arcidegbénulás, myasthenia, mye-

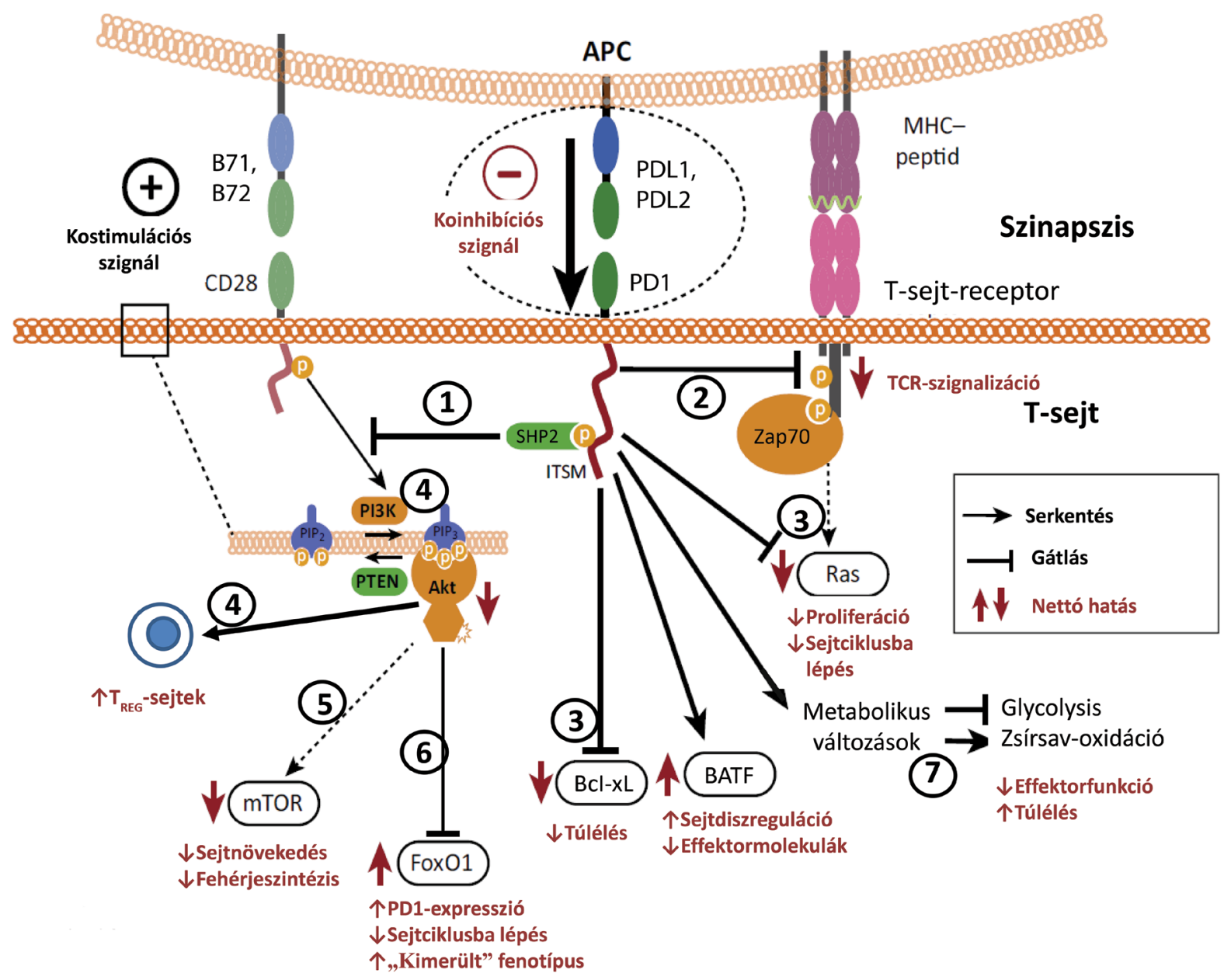

7. ábra

A PD1-PDL1/L2 kapcsolódást követő intracelluláris szignalizációs mechanizmusok a T-sejtben. A PD1-stimuláció (1) az SHP2 foszforilációja révén gátolja a B7-CD28 kostimulációt; (2) az elsődleges TCR PIP-MHC kölcsönhatásból eredő Zap70-foszforilációt és a következményes T-sejt-aktivációs folyamatokat gátolja; (3) a Bcl-xL és Ras gátlása révén gátolja a sejtek túlélését és fokozza az apoptózist; (4) a B7-CD28 kostimuláció aktiválja a a $\mathrm{PIP}_{3} / A k t$ komplexet. A PDl múködése gátolja ezt a folyamatot is, és ezen keresztül serkenti a regulátor T-sejtek $\left(\mathrm{T}_{\mathrm{REG}}\right)$ múködését; $(5)$ a PIP $3 / \mathrm{Akt}$ komplex serkentené az mTOR-t is, a PDl révén ez gátlódik, és ezáltal a sejtek növekedése és fehérjeszintézise is; (6) az Akt ugyancsak gátolja a FoxOl-t, így a PDl ezt felszabadítja. A folyamatos FoxOl-aktiváció a sejten tovább fokozza a PDl-expressziót, circulus vitiosus jön létre, a sejtet „túlhajtja”, és ún. „kimerült" (exhausted) fenotípus jön létre; (7) a PDl anyagcsere-változásokat is indukál: gátolja a normális glycolysist, és serkenti a zsírsav-oxidációt. A PDl vagy PDLl gátlása (ICI) mindezen folyamatokat ellenkező előjellel változtatja meg ([42] nyomán)

MHC = major hisztokompatibilitási komplex; $\mathrm{mTOR}=$ a rapamicin célpontja emlősökben; PDl = programozott halál-1; PDLl = programozott halál ligandum-1; PIP = foszfatidil-inozitol; TCR = T-lymphocyták receptora 
3. táblázat |Az egyes antireumatikus gyógyszerek hatékonysága és gyakorlatban való alkalmazása immuncheckpointgátló mellékhatásainak kezelésére [46]

\begin{tabular}{|c|c|c|c|c|c|}
\hline & NSAID & Kortikoszteroid & csDMARD & bDMARD & IVIG/PEX \\
\hline \multicolumn{6}{|l|}{ Arthritis } \\
\hline Hatékonyság & + & +++ & ++ & +++ & $?$ \\
\hline Használat & + & +++ & ++ & + & - \\
\hline \multicolumn{6}{|l|}{ PMR } \\
\hline Hatékonyság & $?$ & +++ & $?$ & +++ & $?$ \\
\hline Használat & - & +++ & - & $+/-$ & - \\
\hline \multicolumn{6}{|l|}{ Myositis } \\
\hline Hatékonyság & $?$ & ++ & ++ & + & ++ \\
\hline Használat & - & +++ & + & $+/-$ & ++ \\
\hline \multicolumn{6}{|l|}{ Vasculitis } \\
\hline Hatékonyság & $?$ & ++ & ++ & $?$ & $?$ \\
\hline Használat & - & +++ & + & - & - \\
\hline \multicolumn{6}{|c|}{ Sjögren-szindróma/siccatünetek } \\
\hline Hatékonyság & $?$ & ++ & $?$ & $+/-$ & $+/-$ \\
\hline Használat & - & +++ & - & $+/-$ & $+/-$ \\
\hline
\end{tabular}

A táblázat bizonyos gyógyszercsoportok hatékonyságát és azt mutatja, hogy a gyakorlatban milyen gyakran használják őket.

$+++=$ a betegek > 50\%-ában használják / igen hatékony; ++ = a betegek 10-50\%-ában használják / közepesen hatékony; + = a betegek < $10 \%$-ában használják / kissé hatékony; +/- = egyes esetközlések vannak; - = nem használatos; ? = nem ismert

4. táblázat $\mid$ Ajánlás az autoimmun-reumatológiai mellékhatások kezelésére $[7,48]$

\begin{tabular}{llll}
\hline Súlyossági fokozat & Első vonalbeli kezelés & Másodvonalbeli kezelés & Checkpointgátló terápia? \\
\hline I. (enyhe) & $\begin{array}{l}\text { NSAID } \\
\text { Intraarticularis kortikoszteroid }\end{array}$ & Folytatás \\
\hline II. (középsúlyos) & $\begin{array}{l}\text { Kis dózisú kortikoszteroid }(0,5 \mathrm{mg} / \mathrm{kg}) \\
\text { Intraarticularis kortikoszteroid }\end{array}$ & Átmeneti felfüggesztés \\
\hline III. (súlyos) & Kortikoszteroid $(1-1,5 \mathrm{mg} / \mathrm{kg})$ & bDMARD, metotrexát, szulfaszalazin, klorokin & Leállítás \\
\hline IV. (életet veszélyeztető) & Kortikoszteroid $(1-1,5 \mathrm{mg} / \mathrm{kg})$ & bDMARD, metotrexát, szulfaszalazin, klorokin & Leállítás \\
\hline
\end{tabular}

bDMARD = biológiai terápia; NSAID = nemszteroid gyulladásgátló

litisek, asepticus meningitis, Guillain-Barré-szindróma), a kültakarót (pruritus, kiütések), sokkal ritkábban a szemet (uveitis, keratitis, dacryadenitis, retinopathia), a vesét (nephritis) és a májat is (hepatitis). Az általános tünetek közül a fáradtság, kimerültség a vezető panasz [7, 43].

A terápia és követés során ICI-kezelés előtt, illetve a kezelés alatt rendszeresen dokumentálni és ellenőrizni kell a beteg tüneteit (3. és 4. táblázat). A 3. táblázat alapján látható, hogy mely, a reumatológiában használatos gyógyszerek hatékonyak a mellékhatások kezelésére, és a gyakorlatban melyeket milyen gyakran alkalmazzák. Egy javasolt algoritmus alapján a legenyhébb tünetek esetén az immunterápia (néhány hematológiai és neurológiai eltérés kivételével) folytatható, de már I. fokozatú, enyhe toxicitás esetén is szorosan kell kontrollálni a beteget. Közepes erôsségű (II. fokozatú) mellékhatás esetén óvatosság szükséges az immunterápia folytatását illetően, illetve alacsony dózisú kortikoszteroid-kezelés indítása mérlegelendő. Középsúlyos nemkívánatos esemény esetén szisztémás kortikoszteroid-kezelés javasolt, minimum 4-6 hétig: II. fokozatú mellékhatás esetén általában 0,5$1 \mathrm{mg} / \mathrm{kg}$, III. fokozat esetén legalább $1-1,5 \mathrm{mg} / \mathrm{kg}$ vagy magasabb dózisban. A kortikoszteroid, az ismert módon, a dózist fokozatosan csökkentve hagyható el a tünetek megszünése után. Az ICI-kezelés abban az esetben folytatható, ha a szövődmény megszünik, vagy I. fokozatúra mérséklődik. Ezzel szemben III. fokozatú nemkívánatos esemény megszűnte után újraindított immunterápia esetén fokozott óvatosság és a beteg igen szoros követése szükséges. Súlyos, életet veszélyeztető (IV. fokozatú) eltérés esetén az immunterápia végleges abbahagyása, a beteg megfelelő intézményben történő hospitalizációja és nagy dózisú szisztémás kortikoszteroid adása szükséges. Ha kétnapos kortikoszteroid- (és szükség esetén antibiotikus) kezelés ellenére sincs javulás, a terápiát más 
immunszuppresszív szerrel (anti-TNF bDMARD, humán intravénás immunglobulin, mikofenolát-mofetil, CYC) kell kiegészíteni (4. táblázat) [7, 46, 48].

\section{Osteoporosis hormondeprivatiós kezelés mellett}

Ismeretes, hogy a csonthomeostasis megőrzésében mind a női, mind a férfi nemi hormonoknak szerepük van. A korábban már említett TGFß például az ösztradiolon keresztül gátolja az osteoblastok és stimulálja az osteoclastok apoptózisát. Az ösztrogének ugyancsak gátolják az IL1- és IL6-mediált csontvesztést, és serkentik az OPG-termelést [49]. Az emlö-, prosztatarák és egyéb, nemi szerveket érintő tumorok kezelésében az aromatázgátlók és az antiandrogén szerek fontos szerepet töltenek be [49]. Ezen nemi hormonok gátlása a csontresorptio fokozódásához és osteoporosishoz vezet [49].

Ami a mechanizmusokat illeti, daganatos betegben egyszerre érvényesülnek a tumor és a daganatellenes kezelés csonthatásai. A hormondeprivatio hatására az ösztradiol és az androgének fent leírt hatásai visszafordulnak. Ennek megfelelően az osteoclastok, felszabadulva a gátlás alól, aktiválódnak, ami fokozott csontresorptiót idéz elő. A csontbontás során olyan szolúbilis mediátorok szabadulnak fel (például növekedési faktorok: IGF, TGF $\beta$, PDGF, valamint csont morfogenetikus protein, BMP és CXCL12-chemokin), amelyek a tumor növekedéséhez vezetnek (8. ábra) [2, 49].

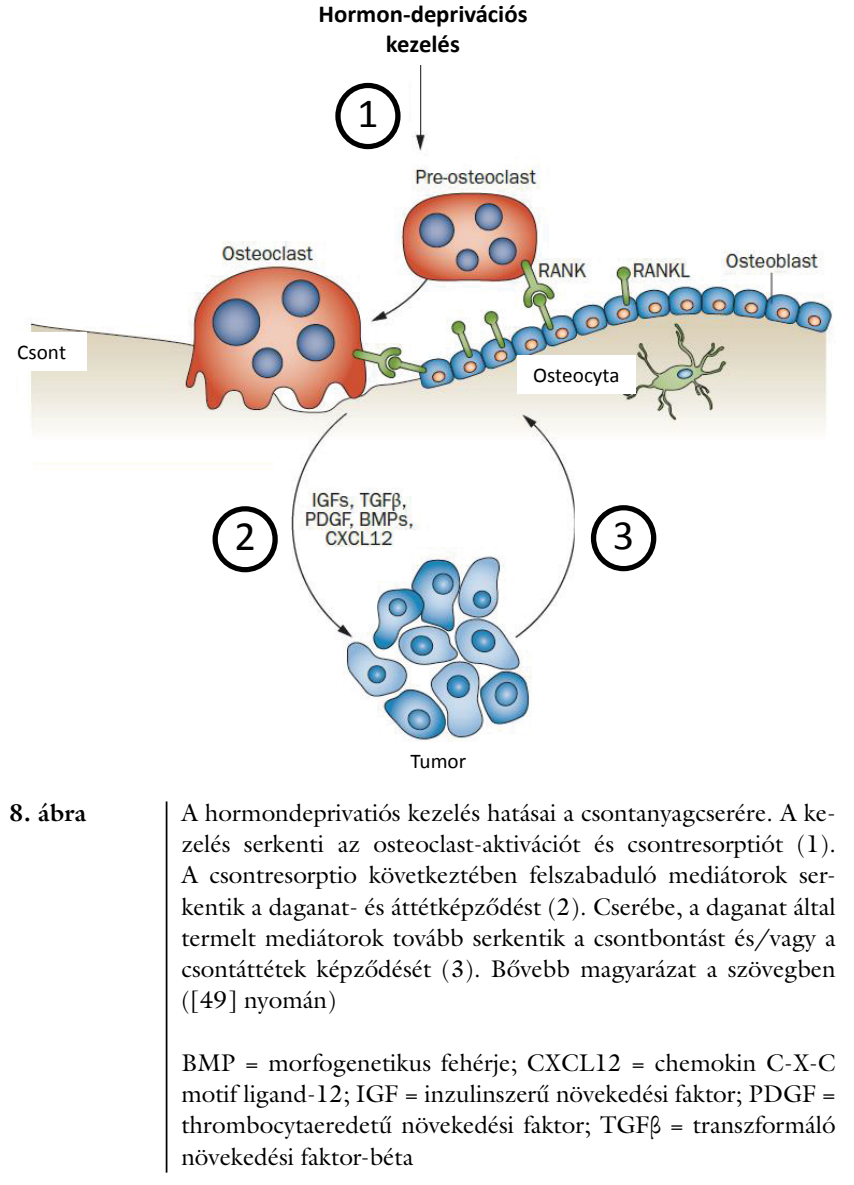

5. táblázat |A mozgásszervi tumorok és terápiájuk

\begin{tabular}{|c|c|c|}
\hline Tumortípus & Altípus & Kezelés \\
\hline \multirow[t]{4}{*}{$\begin{array}{l}\text { Chondro- } \\
\text { sarcoma }\end{array}$} & $\begin{array}{l}\text { Konvencionális } \\
\text { (Grade 1-3.) }\end{array}$ & Nincs standard kemoterápia \\
\hline & $\begin{array}{l}\text { High-grade, } \\
\text { szisztémás } \\
\text { relapsussal }\end{array}$ & $\begin{array}{l}\text { - Ciklofoszfamid } \\
\text { - Szirolimusz }\end{array}$ \\
\hline & Mesenchymalis & Lásd Ewing-sarcoma \\
\hline & Dedifferenciált & Lásd osteosarcomák \\
\hline Chordoma & & $\begin{array}{l}\text { - Imatinib } \\
\text { - Imatinib + ciszplatin vagy } \\
\text { szirolimusz } \\
\text { - Erlotinib } \\
\text { - Szunitinib } \\
\text { - Lapatinib (EGFR + } \\
\text { esetekben) } \\
\end{array}$ \\
\hline \multirow[t]{3}{*}{$\begin{array}{l}\text { Ewing- } \\
\text { sarcoma }\end{array}$} & $\begin{array}{l}\text { Első vonalbeli } \\
\text { (primer/ } \\
\text { neoadjuváns/ } \\
\text { adjuváns) }\end{array}$ & $\begin{array}{l}\text { - VAC/IE (vinkrisztin, } \\
\text { doxorubicin, ciklofoszfamid } \\
\text { alternálva ifoszfamiddal és } \\
\text { etopoziddal) } \\
\text { - VAI (vinkrisztin, doxorubi- } \\
\text { cin, ifoszfamid) } \\
\text { - VIDE (vinkrisztin, } \\
\text { ifoszfamid, doxorubicin, } \\
\text { etopozid) }\end{array}$ \\
\hline & $\begin{array}{l}\text { Kezdettól } \\
\text { metastaticus }\end{array}$ & $\begin{array}{l}\text { - VAdriaC (vinkrisztin, } \\
\text { doxorubicin, ciklofoszfa- } \\
\text { mid) } \\
\text { - VAC/IE } \\
\text { - VAI } \\
\text { - VIDE }\end{array}$ \\
\hline & $\begin{array}{l}\text { Másodvonalbeli } \\
\text { (relabáló/refrakter } \\
\text { vagy metastaticus) }\end{array}$ & $\begin{array}{l}\text { - Ciklofoszfamid és topotekán } \\
\text { - Irinotekán } \pm \text { temozolomid } \\
\text { - Ifoszfamid és etopozid } \\
\text { - Ifoszfamid, karboplatin és } \\
\text { etopozid } \\
\text { - Docetaxel és gemcitabin }\end{array}$ \\
\hline $\begin{array}{l}\text { Óriássejtes } \\
\text { csonttumorok }\end{array}$ & & $\begin{array}{l}\text { - Denoszumab } \\
\text { - Interferon-alfa } \\
\text { - Peginterferon }\end{array}$ \\
\hline \multirow[t]{2}{*}{ Osteosarcoma } & $\begin{array}{l}\text { Első vonalbeli } \\
\text { (primer/ } \\
\text { neoadjuváns/ } \\
\text { adjuváns vagy } \\
\text { metastaticus) }\end{array}$ & $\begin{array}{l}\text { - Ciszplatin és doxorubicin } \\
\text { - MAP (metotrexát, } \\
\text { ciszplatin, doxorubicin) } \\
\text { - Doxorubicin, ciszplatin, } \\
\text { ifoszfamid, metotrexát } \\
\text { - Ifoszfamid, ciszplatin és } \\
\text { epirubicin }\end{array}$ \\
\hline & $\begin{array}{l}\text { Másodvonalbeli } \\
\text { (relabáló/refrakter } \\
\text { vagy metastaticus) }\end{array}$ & $\begin{array}{l}\text { - Docetaxel és gemcitabin } \\
\text { - Ciklofoszfamid és etopozid } \\
\text { - Ciklofoszfamid és topotekán } \\
\text { - Gemcitabin } \\
\text { - Ifoszfamid és etopozid } \\
\text { - Ifoszfamid, karboplatin és } \\
\text { - etopozid } \\
\text { - Metotrexát, etopozid és } \\
\text { ifoszfamid } \\
\text { - }{ }^{153} \text { Sm-EDTMP } \\
\text { (másodvonal után is } \\
\text { - } \text { refrakter) } \\
\text { - Szorafenib }\end{array}$ \\
\hline
\end{tabular}

${ }^{153} \mathrm{Sm}$-EDTMP = szamárium-153-etilén-diamin-tetrametilén-foszfonát; EGFR = becsült glomerulusfiltrációs ráta 
Mindezek miatt a daganatos betegeket csontdenzitometriás szűrésnek kell alávetni és megfelelően kell kezelni. Klinikai adatok elsősorban a biszfoszfonátok (fóleg zoledronát, ibandronát) és a RANKL-gátló antitest, a denoszumab vonatkozásában érhetők el. Emlőrákban a GnRH-analóg mellé adott tamoxifen vagy anasztrozol hatására már 24-26 hónap után jelentős csontvesztés következett be, amit zoledronáttal ki lehetett védeni. Hasonló kedvező adatok vannak denoszumabbal is. Tüneti kezelésként analgetikum, NSAID adható $[2,49,50]$.

A gyakorlatban a hormondeprivatiós kezelés alatt, optimális esetben már annak megkezdésekor csontdenzitometriát (DEXA) kell végezni. Amennyiben a T-score -2 alatt van, vagy $-1,5$ alatt van, biszfoszfonát vagy denoszumab javasolt rendszeres DEXA-ellenőrzés mellett [49].

\section{A mozgásszervrendszer tumorai}

Természetesen a mozgásszervrendszer daganatai is érinthetik a reumatológiai praxist. Ezen összefoglalónak azonban végképp nem lehet célja e hatalmas onkológiai terület áttekintése. Több kitűnő összefoglaló és klinikai vizsgálati eredmény jelent meg a témában hazai szerzők tollából is $[2,12,13]$.

Szövettani szempontból a támasztószövet tumorai (sarcomák) igen heterogén csoportot képviselnek (5. táblázat). A mesenchymalis átalakulásnak számos markere van $[2,12,13]$. Ezek a daganatok a malignus szolid tumorok kb. 0,5-1\%-át teszik ki. Bármely életkorban megjelenhetnek, de gyermekkorban gyakoribbak. Nemi dominancia nincs. Prognózisuk igen rossz: a mútét utáni lokális recidívák aránya és az 5 éven túl megjelenő távoli áttétek aránya is $50 \%$ körül van $[2,12,13]$. Alapvetően két fő csoportra (lágyrész- és csont-) szokás osztani a sarcomákat (5. táblázat) [2, 12, 13].

A klinikum vonatkozásában a lokálisan agresszív növekedés, a gyors progresszió és nehéz kezelhetőségük emelhető ki. Tekintettel arra, hogy kb. 45\%-uk az alsó végtagról, azon belül is $75 \%$-uk a térd fölött alakul ki, egyértelmú, hogy hamar okoznak mozgásszervi tüneteket. A sarcomák okozta leggyakoribb tünetek a fájdalom és a végtagi körfogat növekedése (duzzanat). Az érintett terület fölötti bőr hyperaemiásan elszíneződött lehet. A daganatközeli ízületben mozgásbeszúkülés, reaktív synovitis is hamar kialakul. A láz rossz prognózist jelent. A patológiás törések kockázata $1 \%$ körüli $[2,12,13]$. Néhány saját esetünket a 9. ábra mutatja be.

A differenciáldiagnosztika szempontjából fontos a csontáttétektől történő megkülönböztetés. Például az emlődaganatokra osteolyticus, a prosztatarákra inkább osteoplasticus metastasisok jellemzőek [2, 12, 13].

A támasztószöveti (mozgásszervi) daganatok ellátási protokollja során a már ismert dignitású tumor oki kezeléseként még mindig a sebészi megoldásnak van a legmagasabb kuratív rátája. Megfelelően részletes 'staging'
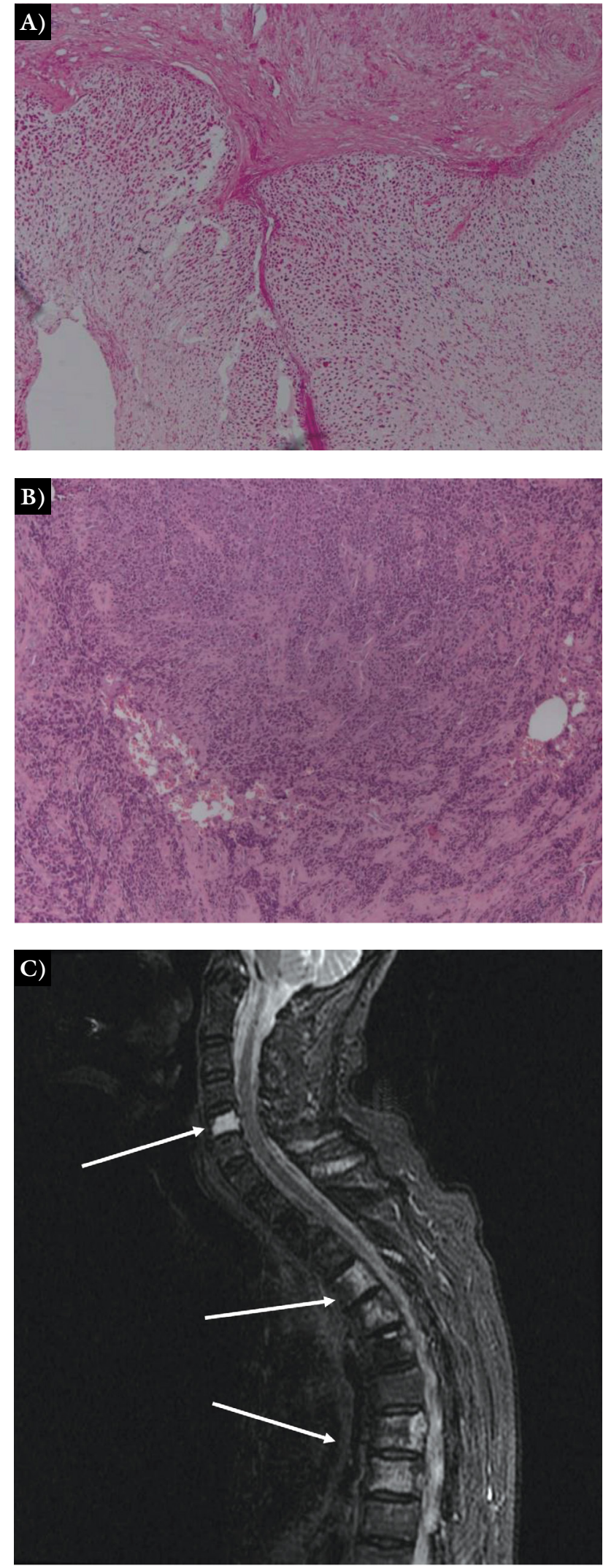

9. ábra

(A) Bordai kiindulású chondrosarcoma: malignus chondrocyták (G3) kötőszöveti infiltrációja (Willian Yi-Che, Kenézy Kórház, Patológiai Osztály, Debrecen, anyagából). (B) Humeruseredetű Ewing-sarcoma: malignus „kis kék kereksejtes” tumorszövet kötőszöveti infiltációja (Willian Yi-Che, Kenézy Kórház, Patológiai Osztály, Debrecen, anyagából). (C) Prosztatatumor multiplex csigolya-metastasisai (nyilak) 
után kombinált kezeléssel érhetô el a legjobb terápiás eredmény. Amennyiben a beteg állapota ezt megengedi, több ciklusból álló kemoterápiás kombinációt (neoadjuváns kezelés) kap a beteg a tervezett mútét előtt. Amenynyiben megfelelő sebgyógyulás már bekövetkezett a mûtét után, kiegészítő (adjuváns) kemoterápiát is kap a beteg $[2,12,13]$. A sarcomák relatíve sugárrezisztensek $[2,12,13]$. A szisztémás kezelésben alkalmazott gyógyszereket az 5. táblázat mutatja $[2,12,13]$.

Végül, a tumoros fájdalomcsillapítás a WHO analgetikus lépcsői szerint történik (analgetikum/NSAID, minor, majd major opiát). A fájdalomcsillapításra vonatkozó mai álláspont szerint kiegészítésként kortikoszteroid, különböző antidepresszánsok is alkalmazhatók [2].

Anyagi támogatás: A munka az Európai Unió Szociális Alap TÁMOP-4.2.4.A/2-11/1-2012-0001. sz. „Nemzeti Kiválóság Program" (Sz. Z.), valamint az Európai Unió GINOP-2.3.2-15-2016-00015. (Sz. Z.) sz. programjának támogatásával készült.

Szerzői munkamegosztás: Sz. Z.: A koncepció kidolgozása, irodalomkutatás, a kézirat megírása. G. I., S. B., B. L., Sz. Sz., A. Cs., J. B., V. L., A.-Sz. P., Sz. P., B. N., Á. P., I. Á., Sz. G., D. K., B. T., T. L.: Adatok szolgáltatása és a kézirat javítása. Sz. É.: Adatgyüjtés, részvétel a koncepció kidolgozásában és a kézirat megírásában. A cikk végleges változatát valamennyi szerző elolvasta és jóváhagyta.

Érdekeltségek: A szerzőknek nincsenek érdekeltségeik.

\section{Irodalom}

[1] Szekanecz Z, Szekanecz É, Bakó G, et al. Malignancies in autoimmune rheumatic diseases - a mini-review. Gerontology 2011; 57: 3-10.

[2] Szekanecz É. Relationship between oncologic and rheumatic diseases. In: Szekanecz Z, Nagy Gy. (eds.) Reumatology. [Az onkológiai és reumatológiai kórképek összefüggései. In: Szekanecz Z, Nagy Gy. (szerk.) Reumatológia.] Medicina Könyvkiadó, Budapest, 2019; pp. 933-940. [Hungarian]

[3] Szekanecz É, András C, Sándor Z, et al. Malignancies and soluble tumor antigens in rheumatic diseases. Autoimmun Rev. 2006; 6: 42-47.

[4] Szekanecz É, András Cs, Kiss E, et al. Rheumatic diseases and malignancies - paraneoplastic syndromes. [Reumatológiai paraneoplasiás szindrómák.] Lege Artis Med. 2006; 16: 749-756. [Hungarian]

[5] András Cs, Szántó J, Szekanecz Z, et al. A clinical importance of rheumatological paraneoplasias. [A reumatológiai paraneopláziák klinikai jelentősége.] Magy Immunol. 2006; 5: 4-11. [Hungarian]

[6] Szekanecz É, Szúcs G, Kiss E, et al. Secondary malignancies in rheumatoid arthritis. [Szekunder malignus tumorok előfordulása rheumatoid arthritisben.] Lege Artis Med. 2008; 18: 886-892. [Hungarian]

[7] Szekanecz É, Szekanecz Z. Autoimmune side effects of immunecheckpoint inhibitor therapies in oncology: pathogenesis, clinic and treatment. [Az onkológiában alkalmazott immuncheck- pointgátló terápiák autoimmun mellékhatásai: patogenezis, klinikum és terápia.] Orv Hetil. 2019; 160: 887-895. [Hungarian]

[8] Gálffy G. Side-effects of immunotherapies and their treatment. [Az immunterápiák mellékhatásai és kezelésük.] Immunol Szle. 2017; 9: 12-14. [Hungarian]

[9] Géczi L. Immunotherapy: new way of anticancer pharmacotherapy in urology. [Immunterápia: a daganatellenes gyógyszeres kezelés új lehetősége az urológia területén.] Háziorv Továbbk Szle. 2018; 23: 513-514. [Hungarian]

[10] Ostoros G. Immunotherapy of lung cancer according to recent advances. [A tüdőrák immunterápiája az újabb eredmények tükrében.] Klin Onkol. 2018; 5: 11-15. [Hungarian]

[11] Liszkay G. Immunotherapy: new way of anticancer pharmacotherapy in skin malignancies. [Immunterápia: a daganatellenes gyógyszeres kezelés új lehetősége a bőrdaganatok területén.] Háziorv Továbbk Szle. 2018; 23: 515-517. [Hungarian]

[12] Szendrói M. New aspects in the treatment of bone sarcomas. Acta Med Hung. 1994; 50: 237-244.

[13] Pápai Z. Assessment of prognostic factors and novel therapeutic modalities in connective tissue tumours. Doctoral thesis. [Prognosztikai faktorok vizsgálata és újabb gyógyszeres kezelési lehetőségek rosszindulatú támasztószöveti daganatok esetén. PhD-értekezés.] Semmelweis Egyetem Doktori Iskola, Budapest, 2002. [Hungarian]

[14] Gomez I, Szekanecz É, Szekanecz Z, et al. Physiotherapy of cancer patients. [Daganatos betegek fizioterápiája.] Orv Hetil. 2016; 157: 1224-1231. [Hungarian]

[15] Elinav E, Nowarski R, Thaiss CA, et al. Inflammation-induced cancer: crosstalk between tumours, immune cells and microorganisms. Nat Rev Cancer 2013; 13: 759-771.

[16] Cutolo M, Paolino S, Pizzorni C. Possible contribution of chronic inflammation in the induction of cancer in rheumatic diseases. Clin Exp Rheumatol. 2014; 32: 839-847.

[17] Nakken B, Alex P, Munthe L, et al. Immune-regulatory mechanisms in systemic autoimmune and rheumatic diseases. Clin Dev Immunol. 2012; 2012: 957151.

[18] Illés A, Váróczy L, Papp G, et al. Aspects of B-cell non-Hodgkin's lymphoma development: a transition from immune-reactivity to malignancy. Scand J Immunol. 2009; 69: 387-400.

[19] Szekanecz É, Szamosi S, Horváth A, et al. Malignancies associated with systemic sclerosis. Autoimmun Rev. 2012; 11: 852855.

[20] Tarr T, Szekanecz É, Zeher M, et al. The occurrence of malignancies in a Hungarian lupus population. [Tumorok előfordulása szisztémás lupus erythematosusos betegek körében.] Orv Hetil. 2006; 147: 2229-2233. [Hungarian]

[21] Váróczy L, Gergely L, Zeher M, et al. Malignant lymphomaassociated autoimmune diseases - a descriptive epidemiological study. Rheumatol Int. 2002; 22: 233-237.

[22] Kovács L, Szodoray P, Kiss E. Secondary tumours in Sjogren's syndrome. Autoimmun Rev. 2009; 9: 203-206.

[23] Simard JF, Neovius M, Hagelberg S, et al. Juvenile idiopathic arthritis and risk of cancer: a nationwide cohort study. Arthritis Rheum. 2010; 62: 3776-3782.

[24] Toussirot E, Roudier J. Epstein-Barr virus in autoimmune diseases. Best Pract Res Clin Rheumatol. 2008; 22: 883-896.

[25] Reynisdottir G, Karimi R, Joshua V, et al. Structural changes and antibody enrichment in the lungs are early features of anti-citrullinated protein antibody-positive rheumatoid arthritis. Arthritis Rheum. 2014; 66: 31-39.

[26] Czirják L, Kumánovics G, Varjú C, et al. Survival and causes of death in 366 Hungarian patients with systemic sclerosis. Ann Rheum Dis. 2008; 67: 59-63.

[27] András Cs, Bodoki L, Nagy-Vincze M, et al. Retrospective analysis of cancer-associated myositis patients over the past 3 decades in a Hungarian myositis cohort. Pathol Oncol Res. 2019 Oct 23. Doi: 10.1007/s12253-019-00756-4. [Epub ahead of print] 
[28] Haas OA. Primary immunodeficiency and cancer predisposition revisited: embedding two closely related concepts into an integrative conceptual framework. Front Immunol. 2018; 9: 3136.

[29] Hellgren K, Dreyer L, Arkema EV, et al. Cancer risk in patients with spondyloarthritis treated with TNF inhibitors: a collaborative study from the ARTIS and DANBIO registers. Ann Rheum Dis. 2017; 76: 105-111.

[30] Soltész P, Szekanecz Z, Végh J, et al. Catastrophic antiphospholipid syndrome in cancer. Haematologia 2000; 30: 303-311.

[31] Baecklund E, Iliadou A, Askling J, et al. Association of chronic inflammation, not its treatment, with increased lymphoma risk in rheumatoid arthritis. Arthritis Rheum. 2006; 54: 692-701.

[32] Watad A, McGonagle D, Bragazzi NL, et al. Autoantibody status in systemic sclerosis patients defines both cancer risk and survival with ANA negativity in cases with concomitant cancer having a worse survival. Oncoimmunology 2019; 8: el588084.

[33] Gabrilovich DI, Chen HL, Girgis KR, et al. Production of vascular endothelial growth factor by human tumors inhibits the functional maturation of dendritic cells. Nat Med. 1996; 2: 10961103. [Correction: Nat Med. 1996; 2: 1267.]

[34] Catrina AI, Deane KD, Scher JU. Gene, environment, microbiome and mucosal immune tolerance in rheumatoid arthritis. Rheumatology (Oxford) 2016; 55: 391-402.

[35] Ramiro S, Gaujoux-Viala C, Nam JL, et al. Safety of synthetic and biological DMARDs: a systematic literature review informing the 2013 update of the EULAR recommendations for management of rheumatoid arthritis. Ann Rheum Dis. 2014; 73: 529-535.

[36] Wadström H, Frisell T, Askling J, et al. Malignant neoplasms in patients with rheumatoid arthritis treated with tumor necrosis factor inhibitors, tocilizumab, abatacept, or rituximab in clinical practice: a nationwide cohort study from Sweden. JAMA Intern Med. 2017; 177: 1605-1612.

[37] Sivaraman P, Cohen SB. Malignancy and Janus kinase inhibition. Rheum Dis Clin North Am. 2017; 43: 79-93.

[38] Raaschou P, Söderling J, Turesson C, et al. Tumor necrosis factor inhibitors and cancer recurrence in Swedish patients with rheumatoid arthritis: a nationwide population-based cohort study. Ann Intern Med. 2018; 169: 291-299.

[39] Buffart LM, Kalter J, Sweegers MG, et al. Effects and moderators of exercise on quality of life and physical function in patients with cancer: an individual patient data meta-analysis of 34 RCTs. Cancer Treat Rev. 2017; 52: 91-104.
[40] Manger B, Schett G. Paraneoplastic syndromes in rheumatology. Nat Rev Rheumatol. 2014; 10: 662-670.

[41] Szekanecz Z, Szekanecz É. Immunological and immunooncological role of PD-1 and PD-Ll. [A PD-1 és a PD-Ll immunológiai és immunoonkológiai szerepe.] Immunol Szle. 2017; 9: 23-27. [Hungarian]

[42] Chinai JM, Janakiram M, Chen F, et al. New immunotherapies targeting the PD-1 pathway. Trends Pharmacol Sci. 2015; 36: 587-595.

[43] Calabrese LH, Calabrese C, Cappelli LC. Rheumatic immunerelated adverse events from cancer immunotherapy. Nat Rev Rheumatol. 2018; 14: 569-579.

[44] Dai S, Jia R, Zhang X, et al. The PD-1/PD-Ls pathway and autoimmune diseases. Cell Immunol. 2014; 290: 72-79.

[45] Le Mercier I, Lines JL, Noelle RJ. Beyond CTLA-4 and PD-1, the generation $\mathrm{Z}$ of negative checkpoint regulators. Front Immunol. 2015; 6: 418 .

[46] Leipe J, Mariette X. Management of rheumatic complications of ICI therapy: a rheumatology viewpoint. Rheumatology (Oxford) 2019; 58(Suppl 7): vii49-vii58.

[47] Raptopoulou AP, Bertsias G, Makrygiannakis D, et al. The programmed death 1 /programmed death ligand 1 inhibitory pathway is up-regulated in rheumatoid synovium and regulates peripheral $\mathrm{T}$ cell responses in human and murine arthritis. Arthritis Rheum. 2010; 62: 1870-1880.

[48] Haanen JB, Carbonnel F, Robert C, et al. Management of toxicities from immunotherapy: ESMO Clinical Practice Guidelines for diagnosis, treatment and follow-up. Ann Oncol. 2018; 29(Suppl 4): iv264-iv266.

[49] Coleman RE, Rathbone E, Brown JE. Management of cancer treatment-induced bone loss. Nat Rev Rheumatol. 2013; 9: 365-374.

[50] Coleman R, de Boer R, Eidtmann H, et al. Zoledronic acid (zoledronate) for postmenopausal women with early breast cancer receiving adjuvant letrozole (ZO-FAST study): final 60-month results. Ann Oncol. 2013; 24: 398-405.

(Szekanecz Zoltán dr., Debrecen, Nagyerdei krt. 98., 4032 e-mail: szekanecz.zoltan@med.unideb.hu)

\section{"Mutare quod non possis, ut natum est, feras." (Amin nem tudsz változtatni, úgy türd, ahogy van.)}

A cikk a Creative Commons Attribution 4.0 International License (https://creativecommons.org/licenses/by/4.0/) feltételei szerint publikált Open Access közlemény, melynek szellemében a cikk bármilyen médiumban szabadon felhasználható, megosztható és újraközölhető, feltéve, hogy az eredeti szerző és a közlés helye, illetve a CC License linkje és az esetlegesen végrehajtott módosítások feltüntetésre kerülnek. (SID_1) 